\title{
1. DEEP SEA DRILLING PROJECT LEG 62, NORTH CENTRAL PACIFIC OCEAN: INTRODUCTION, CRUISE NARRATIVE, PRINCIPAL RESULTS, AND EXPLANATORY NOTES ${ }^{1}$
}

\author{
Jörn Thiede, Department of Geology, University of Oslo, Blindern, Oslo 3, Norway, \\ Tracy L. Vallier, U.S. Geological Survey, Menlo Park, California \\ and \\ Charles G. Adelseck, Deep Sea Drilling Project, Scripps Institution of Oceanography, La Jolla, California
}

\section{INTRODUCTION}

The Pacific is the world's largest ocean. Although the oldest recovered oceanic basement is probably only of Jurassic age (or perhaps somewhat older; Fig. 1; Fischer et al., 1970), the Pacific's geologic history can be traced to the Paleozoic and early Mesozoic Panthalassa, but traces of its early pre-Jurassic history must now be sought along the remains of Paleozoic and early Mesozoic subduction zones. Because of its age, the Pacific Ocean was expected to provide possibilities of sampling very old plankton communities, from a time when the evolution of the most important plankton groups started (Tappen and Loeblich, 1971). In addition, information was expected concerning the evolution of the early and late Cenozoic plankton communities, as well as their record of the deterioration of global climate during Tertiary and Quaternary times. The modern hydrography of North Pacific Ocean surface water (Sverdrup et al., 1942) is characterized by narrow boundary currents which flow clockwise around the central subtropical gyre and counterclockwise around the subarctic gyre. Temperatures and salinities of North Pacific surface waters (Fig. 2) are highly variable. They allow the distinction of a number of different water masses, and the steep hydrographic gradients separating them have led to a strong provincialism (McGowan, 1974) of a small number of modern faunal and floral plankton communities of broad geographic extent.

One important objective for understanding the evolution of pelagic communities is the sampling of the Jurassic and Cretaceous sediments in the Pacific. During these periods, several major groups of pelagic microorganisms apparently began, or were just beginning, their radiation in the oceans. Evidence from sedimentary rocks formed in marginal seas indicates that calcareous nannoplankton were undergoing major diversification. Planktonic foraminifers, diatoms, and silicoflagellates first appeared and radiated then, and tintinnids, although they appeared first in the early Paleozoic, became abundant and diverse. Thus, this part of the Mesozoic apparently represents a major change in the structure and evolution of pelagic communities. To understand this radiation better, a detailed record of truly pelagic sediments is necessary.

\footnotetext{
${ }^{1}$ Initial Reports of the Deep Sea Drilling Project, Volume 62.
}

In the present North Pacific Ocean, planktonic organisms comprise a small number of communities of broad geographic extent (Fig. 2). Factors which determined the characteristics and coherence of these communities can be understood better by tracing their development through the Neogene. It is likely, but by no means certain, that they have persisted throughout the Neogene, although they may have undergone pronounced changes. In order to understand the history of the present patterns, it is necessary to investigate the Neogene records of each major community and some of the principal zones of transition between them. Regional distributions of several communities should be probed in at least two places in order to provide information on their geographical variation, which in turn can be used to investigate differences between communities. Determinations of certain aspects of the communities require carefully planned investigations. These aspects include:

1) Persistence or transience of dominance patterns within each community, the degree and rates of any changes, as well as possible relationships to environmental factors;

2) Variabilities of individual members of the communities, as they can be related to environmental or community changes;

3) Extent to which changes in the communities are due to changes in indigenous species, and to invasion by non-indigenous forms;

4) Any evidence of synchronous evolutionary changes in taxonomically distinct lineages within individual communities;

5) Whether the process of character displacement, which forms a prominent component of modern evolutionary theory, is widely recognizable in planktonic organisms;

6) Indications of the stability or instability of the main water masses, and whether any observed changes are synchronous from one to the other;

7) The history and distribution of upwelling regimes, both coastal and at major divergences; and

8) The extent and direction of exchange of plankton between the Atlantic and Pacific during periods of submergence of the Panamanian region and of open seaways through the Arctic Ocean.

Several times in the geologic past, pelagic organisms have shown mass extinction and subsequent evolution- 


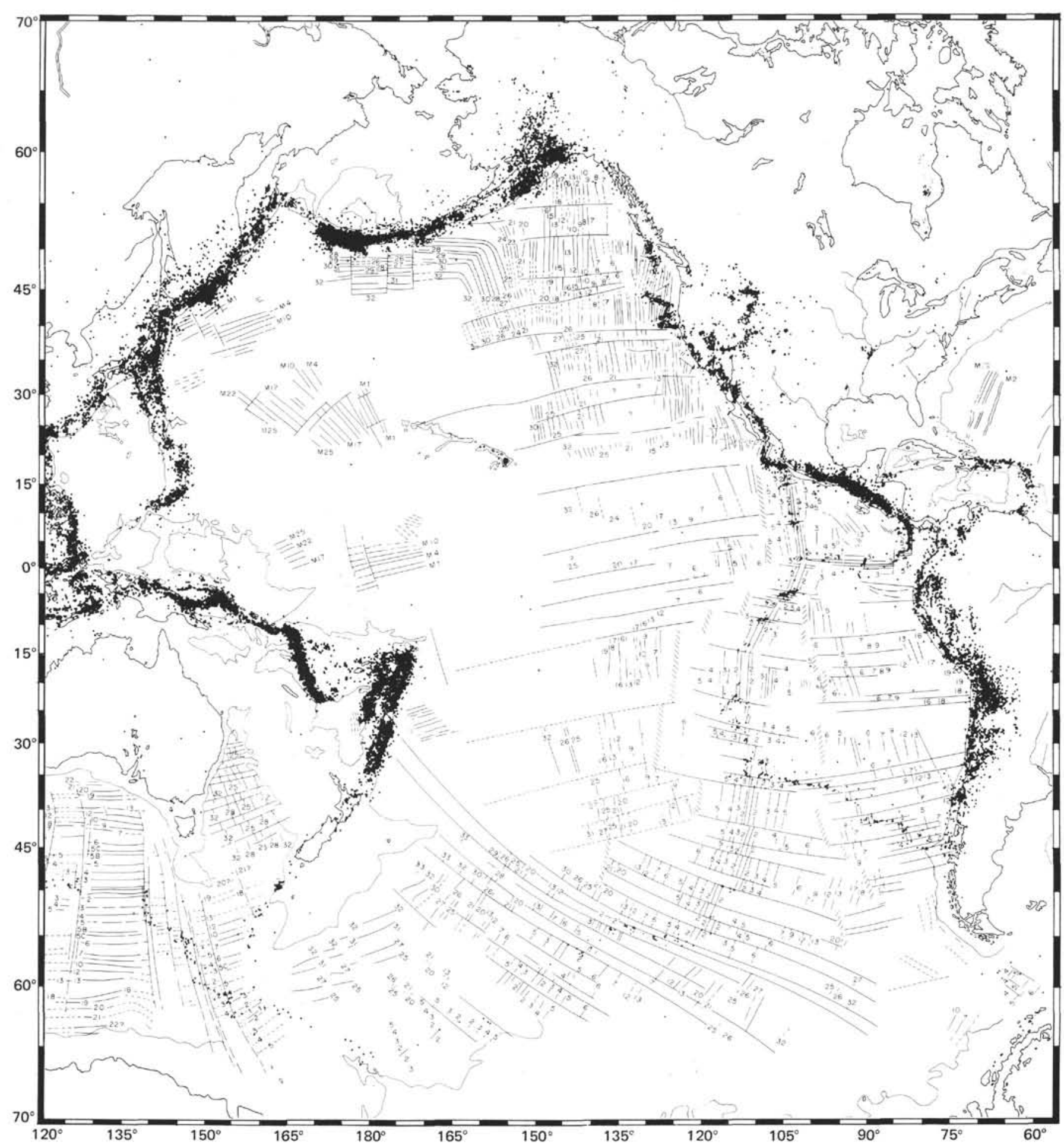

Figure 1. Magnetic anomalies on the Pacific Plate (after Pitman et al., 1974).

ary radiation. Periods of mass extinction are characterized by decreased species diversity, simple morphology, and perhaps cosmopolitan distribution of species. The radiations are characterized by increasing species diversity, complex morphologies, and provincial distributions. These evolutionary cycles represent large-scale changes in pelagic-community structure.
Because the structure of modern pelagic communities varies among water masses, sampling of paleoenvironments analogous to modern water masses was designed to test the hypotheses proposed to account for the extinctions and radiation observed in Eocene and Oligocene communities. We probed sites which are representative of different water masses and communities 

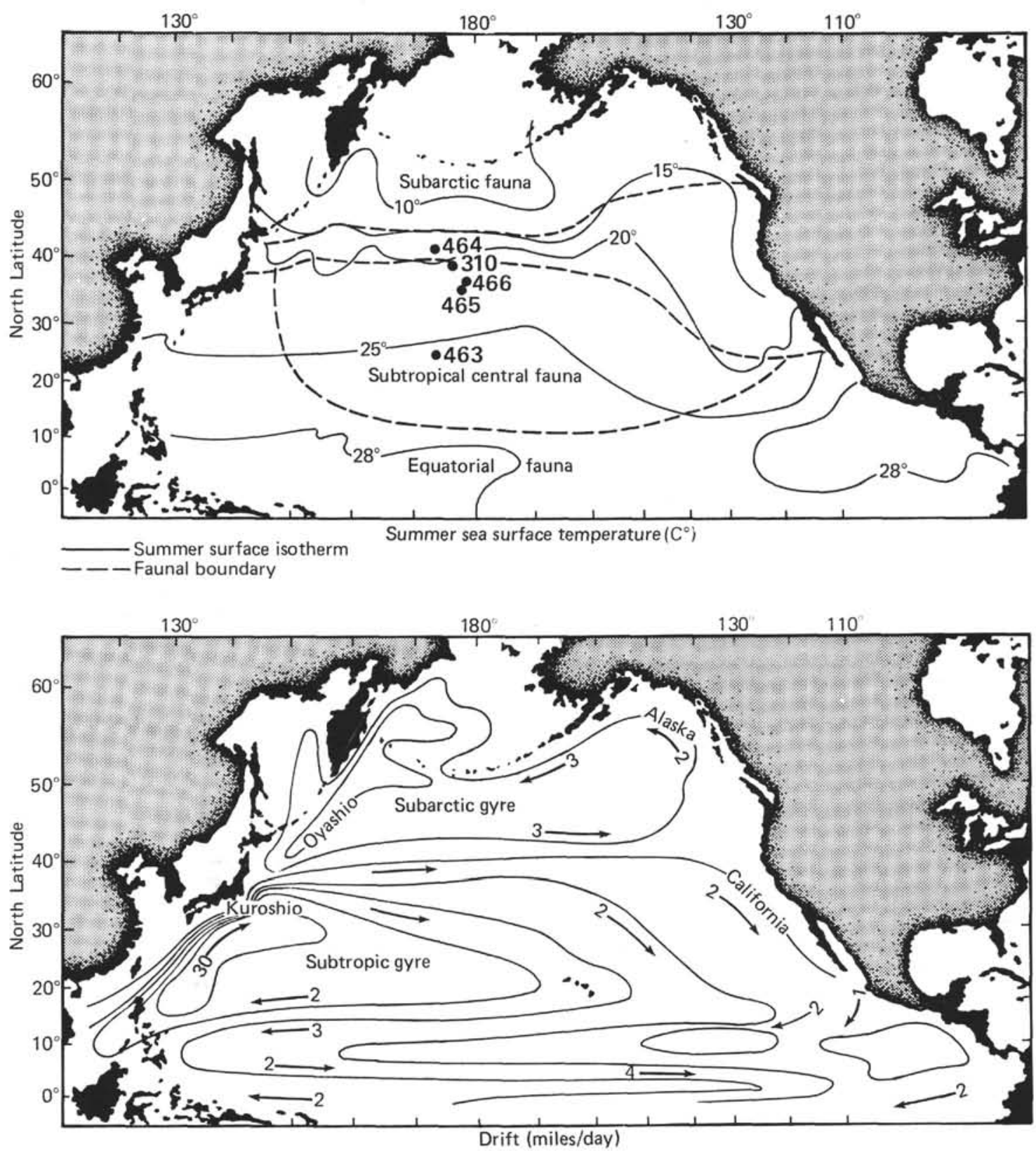

Figure 2. DSDP sites in relation to surface temperatures, living faunal assemblages, and major currents in the North $\mathrm{Pa}$ cific Ocean. Adapted from Bradshaw (1959), Tully (1965), and Vincent (1975).

through this time (Eocene-Oligocene). Locations under the central gyre, equatorial upwelling, eastern tropical Pacific, and subarctic zones were primary targets.

With adequate samples from each of these zones, the following hypotheses can be tested:

1) That changing climates affecting oceanographic regimes have caused the significant changes in community structure;

2) That changes in nutrient input to the oceans through tectonic or oceanographic phenomena caused restructuring of the communities;

3) That transgressions and regressions provide varying areas for species and for isolation of peripheral biotas, thus resulting in additional species;
4) That changing circulation patterns in response to changing continental configurations have affected evolution;

5) That changing vertical structure of the water column is important in the adaptive radiations and extinctions;

6) That the stability or instability of trophic levels and predation affect community structure and evolution.

As part of a program developed by a working group ("Evolution of Planktonic Communities") set up by the JOIDES Ocean Paleoenvironment Panel in 1975, we examined late Mesozoic and Cenozoic paleoenvironments in the central North Pacific Ocean during DSDP Leg 62. 
The drilling program was specifically designed to contribute to the understanding of the history of pelagic sedimentation and of the evolution of planktonic communities in the North Pacific Ocean. The four sites drilled during Leg 62 (Fig. 3A) were needed to establish better regional coverage. A selection of good coring records from the central Pacific Ocean is shown in Figure 3B (back pocket, this volume).

Although paleoenvironments were to be stressed on Leg 62, studies of igneous rocks from acoustic basement were planned, to determine ages, petrogenesis, alteration effects, rock magnetism, and paleomagnetism of old parts of the Pacific crust. These studies were emphasized in order to establish the early history of oceanic plateaus and whether they are the result of midocean-ridge or intraplate volcanism.

\section{CRUISE NARRATIVE}

\section{Operations}

Glomar Challenger departed Majuro, Marshall Islands, on 29 July 1978, and arrived in Honolulu, Hawaii, on 7 September. Leg 62 originally was scheduled for 57 days, but was shortened to 41 days to allow extra time for finishing Site 462 of Leg 61. As a result, all sites scheduled to be drilled in the Gulf of Alaska were cancelled, and we concentrated our efforts on drilling sites in the central North Pacific. We drilled five holes at

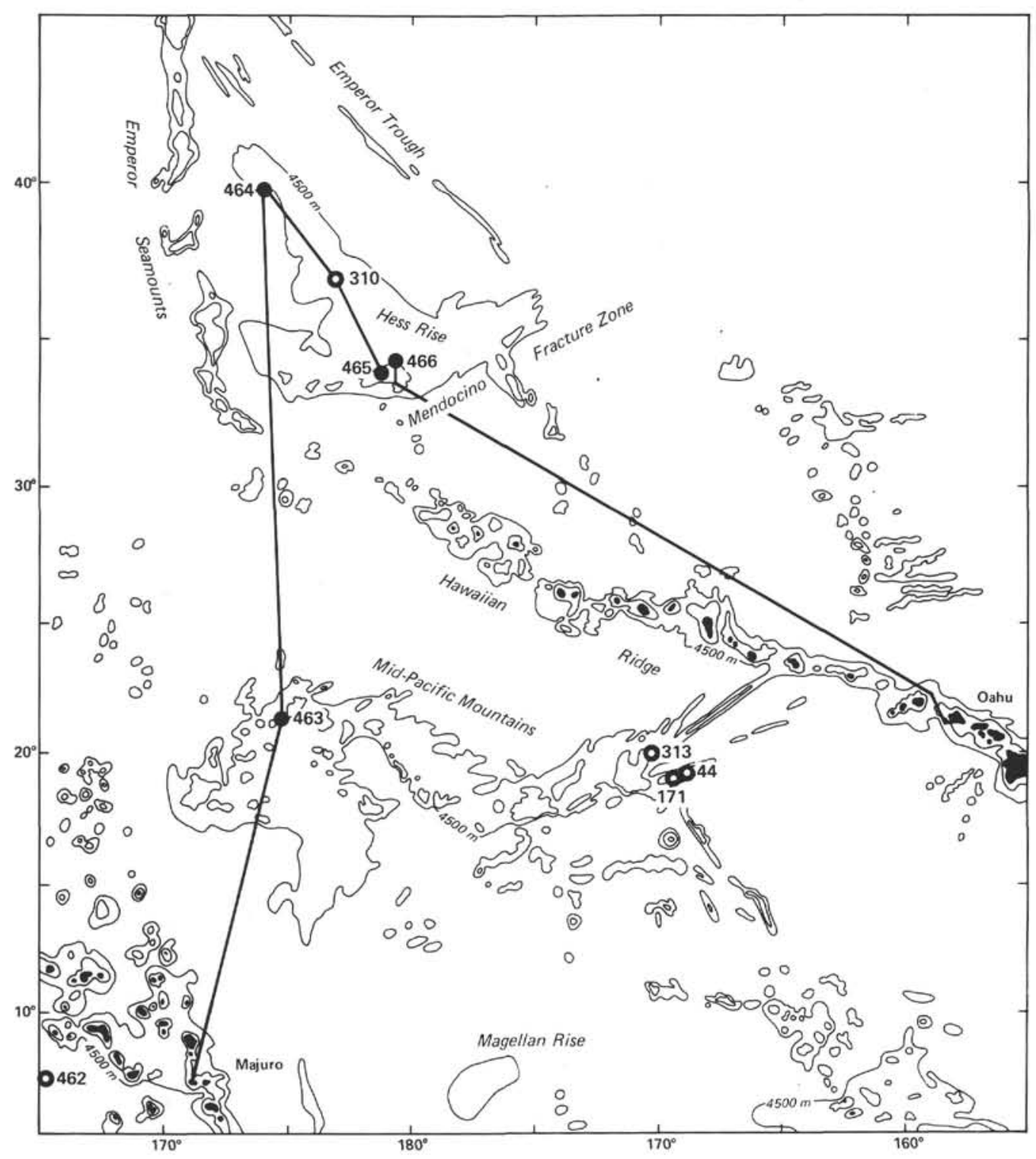

Figure 3A. DSDP sites in the central North Pacific. Course track indicated for Leg 62. (Figure 3B is in the back pocket of this volume.) 
four sites. One site (463) was drilled on the western part of the Mid-Pacific Mountains, and three sites $(464,465$, and 466) were drilled on the Hess Rise (Fig. 3A; Table 1).

Glomar Challenger traveled 3934 nautical miles. Total time was almost equally divided between steaming and drilling. Water depths of the sites ranged from about 2161 to 4637 meters. A total of 218 cores (1976 meters) were cut, and 635.3 meters were recovered. Recovery was a low $32.2 \%$ because of the large amount of chert that was encountered. Coring was continuous at all sites.

\section{Drilling and Coring Assemblies}

A basic bottom-hole assembly was used on Sites 463 and 464 ; it consisted of a bit, butt sub, core barrel, top sub, head sub, three $81 / 4$-in drill collars, one 5 -ft bumper sub, three $81 / 4$-in drill collars, two 5 -ft bumper subs, three $81 / 4$-in drill collars, a cross-over sub, and one joint of $51 / 2-$ in heavy wall pipe. This assembly was changed after we were stuck in Hole 464, in an effort to minimize the chances of again becoming stuck. The change was in the top stand of collars: one $71 / 4$-in collar replaced one of the $81 / 4$-in collars. This assembly was used in Holes $465,465 \mathrm{~A}$, and 466.

A new special core bit used on the first site (463) of Leg 62 was a $93 / 4$-in O.D. $\times 2 \frac{5}{16}$-in F94CP. It cuts a slightly smaller core than the F94CK, but allows use of the new-style pressure core barrel. It performed very well, with 86.26 hours of rotation, penetrating 822.5 meters before it was pulled. At Site 464 , a regular F94CK bit was used, which was lost after 14.6 hours, when the drill string became stuck and was shot off. On Hole 465 and $465 \mathrm{~A}$, another F94CK was used, but was not drilled to destruction, because the pipe stuck again and was pulled when it was not certain if the pipe was intact or not. At Site 466, another 93/4-in O.D. F94CP was run, but was pulled after only 5.35 hours rotating time and 312 meters, when it was necessary to depart for Hawaii. It was in good condition.

During Leg 62, a new pressure core barrel was tested five times at two different sites. This core barrel was designed to maintain sediment at in situ pressure during recovery. None of the holes in which the pressure core barrel was tested was deeper than 3000 meters (total drill-string length), and a great deal of chert was encountered in each of them. However, three of the five tests were successful. The first test was simply a drop test to be sure that the tool would operate properly after falling free to the bottom of the drill string. After the bottom-hole assembly was made up and two stands of pipe were added, the tool was dropped with no damage to the tool. Runs two and three recovered cored material under pressure. The first was in a nannofossil ooze, and the second in chalk and hard ooze with some chert. Test four recovered a few chert chips and no pressure, whereas test five, which had also sampled in a cherty section, had no recovery. From these results, it would appear that the pressure core barrel can be expected to perform best in sediments that do not contain chert. The experience gained with this prototype during the leg assisted greatly in the development of a reliable and useful tool.

\section{PRINCIPAL SCIENTIFIC RESULTS}

\section{Mid-Pacific Mountains, Site 463}

At Site 463 , in the western Mid-Pacific Mountains, the primary objective was to recover upper Mesozoic and Tertiary pelagic carbonate sediments for interpretation of paleoenvironments. A second objective was to obtain samples of the oldest sediment and underlying igneous rocks, to date the volcanic platform. Mesozoic magnetic anomalies northwest of the Mid-Pacific Mountains are Late Jurassic and Early Cretaceous in age, suggesting that the western part of the Mid-Pacific Mountains may be older than its eastern part, which had been sampled during DSDP Legs 6, 17, and 32 .

Coring at Site 463 was continuous to a sub-bottom depth of 822.5 meters. The bit wore out before igneous basement was penetrated. The recovered sediments are divided into four units (Fig. 4). The oldest unit is Lower Cretaceous (upper Barremian and lower Aptian) interbedded clastic and pelagic limestones. Shallow-water debris is common. Paleomagnetism of this unit shows some reversals that may correlate with M0-M3 of the Mesozoic magnetic-anomaly sequence. An overlying unit consists of lower Aptian carbonaceous limestone, marlstone, claystone, and volcanic ash, which contain significant amounts of organic carbon. The next-youngest unit has cyclic alterations of green, white, gray, and pink limestones, which range in age from early Aptian to middle Albian. Chert is abundant. The fourth and youngest lithologic unit is further subdivided into two sub-units: the lower one consists of nannofossil and foraminifer chalk, ooze, and limestone of late Albian to late Maastrichtian age, and the upper sub-unit is upper

Table 1. Leg 62 site summary.

\begin{tabular}{|c|c|c|c|c|c|c|c|c|c|c|c|}
\hline Hole & Latitude & Longitude & $\begin{array}{c}\text { Water } \\
\text { Depth } \\
\text { (m) }\end{array}$ & $\begin{array}{c}\text { Number } \\
\text { of } \\
\text { Cores }\end{array}$ & $\begin{array}{c}\text { Cores } \\
\text { with } \\
\text { Recovery }\end{array}$ & $\begin{array}{l}\text { Meters } \\
\text { Cored }\end{array}$ & $\begin{array}{c}\text { Meters } \\
\text { Recovered }\end{array}$ & $\begin{array}{c}\text { Percent } \\
\text { Recovered }\end{array}$ & $\begin{array}{l}\text { Meters } \\
\text { Drilled }\end{array}$ & $\begin{array}{c}\text { Total } \\
\text { Penetration } \\
\text { (m) }\end{array}$ & $\begin{array}{c}\text { Time } \\
\text { on } \\
\text { Site } \\
\text { (hours) }\end{array}$ \\
\hline 463 & $21^{\circ} 21.01^{\prime} \mathrm{N}$ & $174^{\circ} 40.07^{\prime} \mathrm{E}$ & 2525 & 92 & 92 & 822.5 & 301.8 & 36.6 & & 822.5 & 190.2 \\
\hline 464 & $39^{\circ} 51.64^{\prime} \mathrm{N}$ & $173^{\circ} 53.33^{\prime} \mathrm{E}$ & 4637 & 34 & 34 & 308.5 & 75.66 & 24.5 & & 308.5 & 121.0 \\
\hline 465 & $33^{\circ} 49.23^{\prime} \mathrm{N}$ & $178^{\circ} 55.14^{\prime} \mathrm{E}$ & 2161 & 11 & 11 & 96.0 & 43.89 & 45.7 & & 96.0. & \\
\hline $465 \mathrm{~A}$ & $33^{\circ} 49.23^{\prime} \mathrm{N}$ & $178^{\circ} 55.14^{\prime} \mathrm{E}$ & 2161 & 46 & 45 & 437.0 & 108.5 & 24.8 & 39.0 & 476.0 & 104.5 \\
\hline \multirow[t]{2}{*}{466} & $34^{\circ} 11.46^{\prime} \mathrm{N}$ & $179^{\circ} 15.34^{\prime} \mathrm{E}$ & 2665 & 35 & 33 & 312.0 & 105.42 & 33.7 & & 312.0 & 60.7 \\
\hline & & & Total & 218 & 215 & 1976.0 & 635.27 & 32.1 & 39.0 & 2015.0 & 476.4 \\
\hline
\end{tabular}




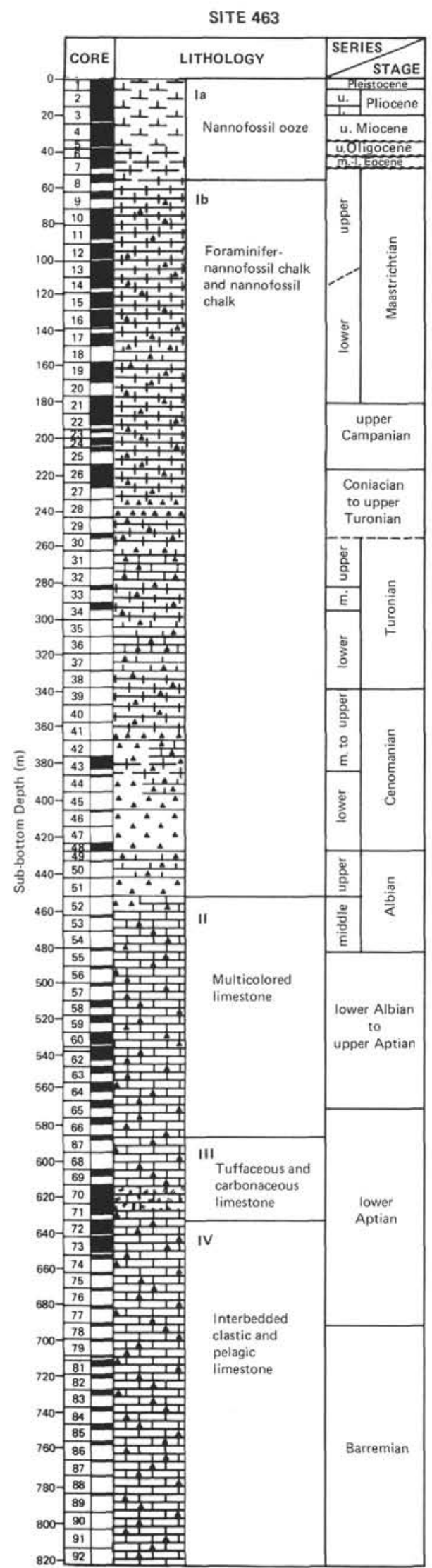

Figure 4. Summary of Leg 62 drilling results.

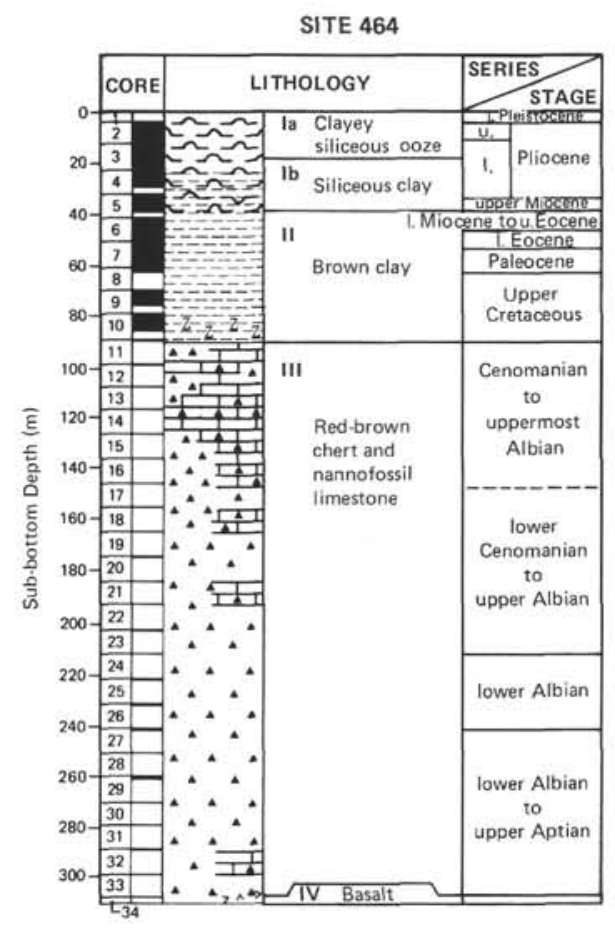


SITE 465

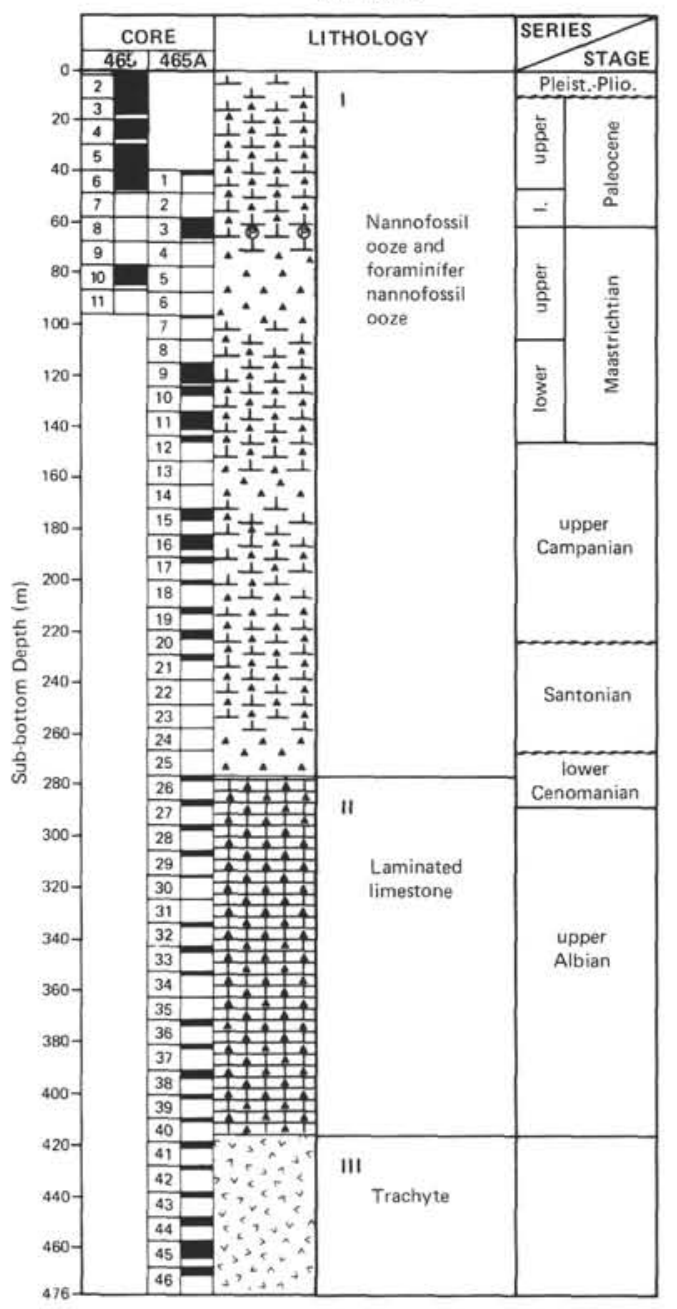

Figure 4. (Continued).

Maastrichtian through Pleistocene nannofossil ooze. Major hiatuses in Hole 463 separate the upper Maastrichtian and lower to middle Eocene, and the upper Oligocene and upper Miocene. Condensed sections with possible hiatuses encompass intervals from the Coniacian through middle Campanian and from the middle Eocene through most of the Oligocene.

It is clear that the Mid-Pacific Mountains are not the same age throughout the province. Oldest sediments recovered at Site 463 are of Barremian age, approximately 15 to 20 m.y. older than those overlying basaltic rocks at Site 171, and about 40 m.y. older than those overlying basalt at Site 313 (Fig. 5). The Mid-Pacific Mountains represent a complex structural high whose segments have been built or added to by volcanic events over a time span of at least 40 to 50 m.y.

The paleodepth of deposition for oldest sediments at Site 463 is difficult to reconstruct because the sediments consist of pelagic limestones that are interbedded with layers rich in clastic, shallow-water calcareous components. Stromatolites, oolites, and mollusk fragments apparently were displaced from an adjacent neritic environment. Dredge hauls from flanks of guyots in other
SITE 466

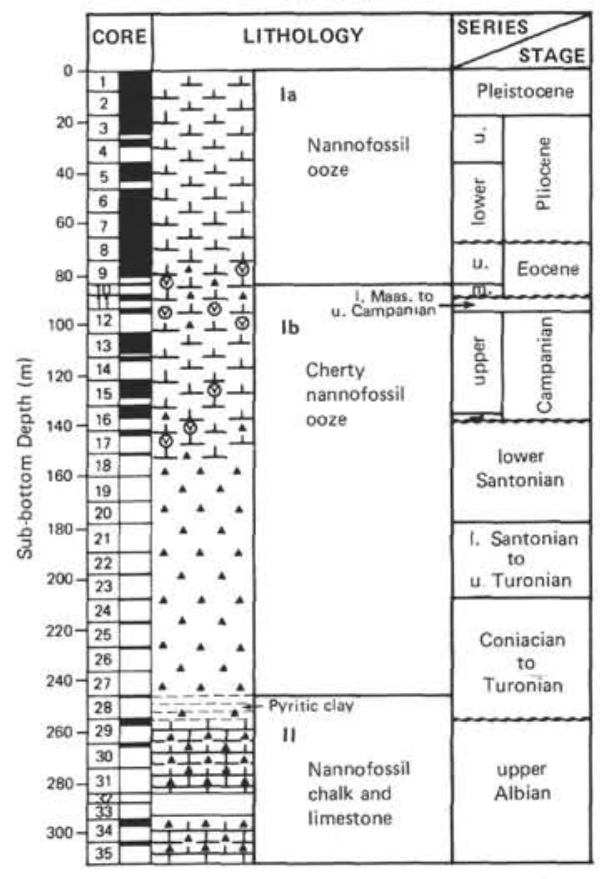

parts of the Mid-Pacific Mountains contain shallowwater fossils which support the conclusion that many of the submarine volcanoes and guyots were islands surrounded by reefs or carbonate banks during much of the Cretaceous. We drilled on the outermost flank of a guyot, and it is apparent that Site 463 is close to one of these Barremian islands. The altered-ash beds of Aptian age in Lithologic Unit III at Site 463 mark a period of volcanic activity which appears to be contemporaneous with the generation of basaltic basement farther east in the Mid-Pacific Mountains.

The ash beds are interbedded with greenish-black to olive-black limestone and marly claystone that have relatively high organic carbon contents suggestive of an oxygen-poor depositional environment. Although most rocks in this interval contain benthic fossils which indicate an oxygenated benthic boundary, the dark, laminated horizons suggest that the interface between the reducing and oxidizing environments at times was no lower than the benthic boundary, and at other times may have moved into the overlying water masses. The development of an oceanic midwater oxygen minimum has been suggested as a possible cause for the wide- 


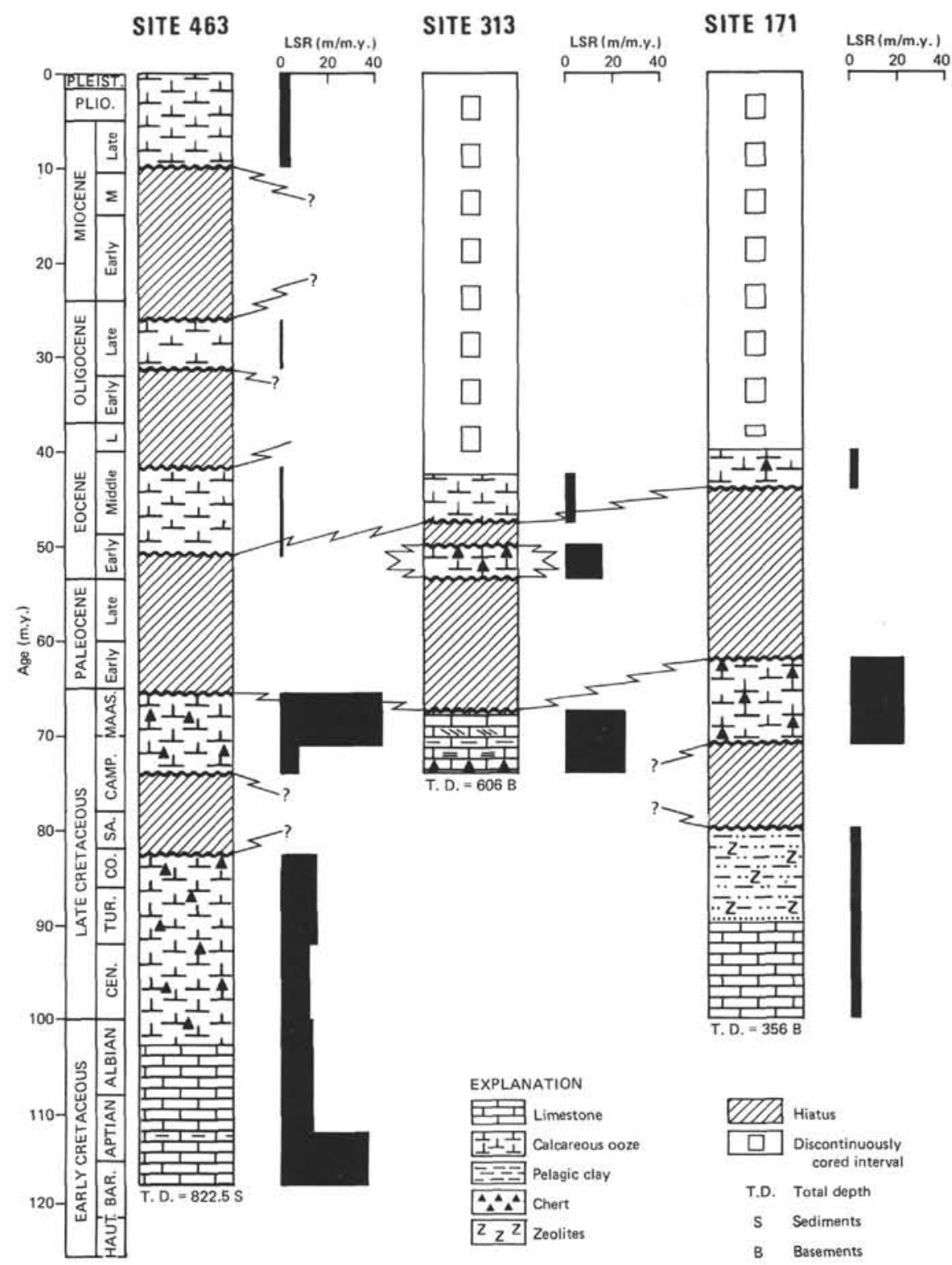

Figure 5. Lithologies, lacunas, and linear sedimentation rates (LSR) of sites drilled in the Mid-Pacific Mountains. Vertical bars in columns of Sites 313 and 171 indicate intervals of discontinuous coring.

spread occurrence of anoxic lithofacies in the world oceans, and our preliminary results support this hypothesis. Re-oxygenation of the ocean floor occurred later in the Aptian, and cyclic, multicolored limestone beds were deposited until the late Albian. Pelagic organisms and a lack of shallow-water debris in the carbonates indicate a pelagic environment with no input from surrounding islands or banks. Displaced materials in this unit consist entirely of siliceous and calcareous remains of fossil plankton.

The Upper Cretaceous calcareous ooze and chalk section at Site 463 is more than 400 meters thick and represents a time when the site passed beneath the highproductivity zone of the equatorial current system.
Significant changes in the sedimentation rates of the dominantly pelagic biogenic deposits suggest that major fluctuations of this current regime are not restricted to the Cenozoic, but that they occurred during the late Mesozoic times as well.

The Cenozoic calcareous-ooze sequence at Site 463 was unexpectedly thin and incomplete. The section is less than 50-meters thick, and includes long hiatuses. The condensed sections between these hiatuses and the deposits of late Miocene and younger ages are typical examples of sediments deposited at the intermediate water depths, well above the $\mathrm{CCD}$, under the oligotrophic central subtropical water mass of the North Pacific. 


\section{Hess Rise}

Hess Rise is one of the major structural features of the north central Pacific. It is a triangular, aseismic high, bounded on the west by the Emperor Seamounts, on the northeast by the Emperor Trough, and on the south by the Mendocino Fracture Zone. Highest parts of the rise are along the southern margin, and the sea floor gradually deepens to the north.

\section{Site 464, Northern Hess Rise}

Northern Hess Rise was continuously cored to a subbottom depth of 308.5 meters at Site 464 , at a water depth of 4637 meters (Figs. 3A and 4; Table 1). The primary objective at this site was to study the evolution of planktonic communities within a high-latitude water mass.

A few fragments of altered tholeiitic basalt were recovered from the bottom of Hole 464 before poor drilling conditions forced abandonment of the site. The rare-earth elements and some of the other trace elements indicate its subalkalic nature, but the existing data do not allow us to place it in a specific geologic setting. It could be either mid-ocean ridge basalt, or the result of intraplate volcanism.

The sediment column above basalt is divided into three major lithologic units (Fig. 4). The oldest is a chert, chalk, and marlstone unit of late Aptian to early Cenomanian age. Unfortunately, recovery of the softer sediments was greatly impeded by abundant chert, and the age control is not good, particularly in the lowest three cores. The second unit is pelagic brown clay that ranges in age from Late Cretaceous to early Miocene. The youngest unit consists of siliceous (diatoms and radiolarians) clay and clayey siliceous ooze of late Miocene to early Pleistocene age.

\section{Sites $\mathbf{4 6 5}$ and 466, Southern Hess Rise}

Three holes were drilled at two sites ( 465 and 466) on southern Hess Rise (Fig. 3A). Site 465 was a primary site, and Site 466 was drilled about $50 \mathrm{~km}$ away to complement data obtained from Site 465 . At Site 465 , we planned to sample a thick section of Neogene sediments that could be used for paleoceanographic studies. We also hoped to penetrate shallow-water sediments and to sample igneous basement. Moreover, by combining the results from Site 465 on southern Hess Rise, Site 310 on central Hess Rise, and Site 464 on northern Hess Rise, we planned to obtain data that could be used to document the migration of Hess Rise under the fertile equatorial regime in the Late Cretaceous.

Two holes ( 465 and $465 \mathrm{~A}$ ) were drilled at Site 465. Hole 465 was continuously cored to a depth of 96 meters and sediments ranging in age from late Maastrichtian to Pleistocene were recovered. The hole was abandoned because of ship-positioning problems. Continuous coring of Hole $465 \mathrm{~A}$ began at 39 meters sub-bottom depth, to sample the Cretaceous/Tertiary boundary, which had been missed in Hole 465. We cored Hole 465A to a depth of 476 meters, which included 412 meters of sediment and 64 meters of trachyte.
The trachyte from Hole $465 \mathrm{~A}$ is highly altered. The original glassy groundmass has been changed to smectite minerals, and the rare primary mafic minerals are replaced. These trachytes are late-stage differentiates of alkali-basalt magma, and they may form a significant part of the southern Hess Rise. Large vesicles up to 5 - $\mathrm{mm}$ in diameter and the massive, non-pillowed nature of the flows suggest that the cored sequence represents shallow-water or subaerial flows. Magnetic intensity and susceptibility of the trachyte samples is low. Inclinations indicate probable eruption at low latitudes. The observed heat flow (1.36 HFU) is similar to the average North Pacific heat flow for crust of this age.

The overlying sediments are divided into two lithologic units (Fig. 4). The oldest is predominantly olivegray laminated limestone of late Albian to early Cenomanian age. Evidence for current erosion and redeposition is common, but no reef or other shallow-water fossil debris occurs in the unit. The youngest sedimentary unit consists of nannofossil and foraminifernannofossil ooze of early Cenomanian to Pleistocene age. Within this unit, we recovered an apparently complete sedimentary sequence across the Cretaceous/Tertiary boundary, with well-preserved sediment of the $G$. eugubina Zone in the lowermost Paleocene.

We failed to find a thick section of Neogene, as anticipated at Site 465 , so with the time remaining we drilled Site 466 , about $50 \mathrm{~km}$ northeast of Site 465 . Coring was continuous to a sub-bottom depth of 312 meters, where we stopped drilling because of time considerations. The upper Albian to Pleistocene sedimentary section contains two major lithologic units, and at least three lacunas. The oldest unit consists of upper Albian limestone and nannofossil chalk, correlative with the lower part of the sedimentary column in Hole 465A. The youngest lithologic unit consists of cherty nannofossil ooze and nannofossil ooze of Coniacian/Turonian through Pleistocene age. The Pliocene and Pleistocene sediments contain a diverse assemblage of siliceous and calcareous microfossils. A zone of middle to late Eocene age contains reworked microfossils as old as Late Cretaceous. Major hiatuses separate the lower Santonian and lower Campanian, the lower Maastrichtian and middle Eocene, and upper Eocene and lower Pliocene. Rounded basalt pebbles in Upper Cretaceous sediments suggest subaerial erosion of surrounding volcanic islands.

Hess Rise is Albian or older, as indicated by the age of oldest sediments at Sites 464, 465, and 466. The trachyte on southern Hess Rise must have been extruded either subaerially or in shallow water, which suggests that the feature probably was above sea level during its early history.

Rapid sedimentation in Albian time on Hess Rise (Fig. 6) appears to be related to high productivity when the site was near the equatorial zone, and to redeposition of sediments. Although it is possible that many of the physical characteristics of the oldest carbonate units can be attributed to distal turbidite sedimentation, the coincidence of laminated sediments, high organic-carbon contents, an oxygen-poor depositional environ- 


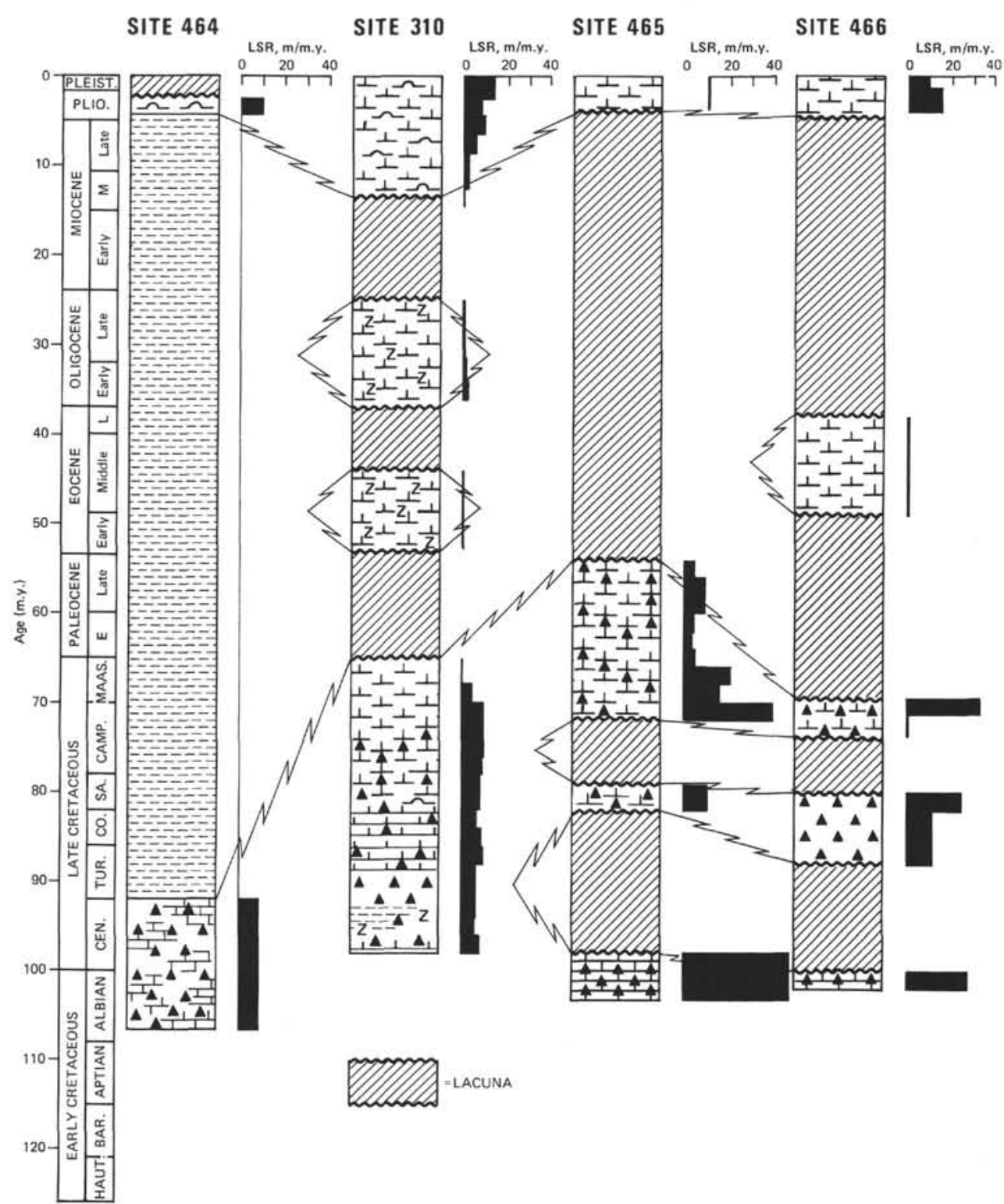

Figure 6. Lithologies, lacunas, and linear sedimentation rates (LSR) on Hess Rise.

ment, high concentrations of radiolarians, and high sedimentation rates points to the likely presence of very fertile surface-water masses of the equatorial highproductivity zone over southern Hess Rise about 90 to 110 m.y. ago.

Our age data indicate that Site 464 formed before the sites on southern Hess Rise. It is likely that the Hess Rise volcanic pedestal formed during late Aptian and early Albian times. The present bathymetry may reflect the original sea-floor topography, but alkali-basalt pebbles found in Campanian sediments at Site 466 suggest that additional tectonism, and possibly volcanism, occurred in the Late Cretaceous.

Important changes of surface water during the global crises at the Mesozoic/Cenozoic boundary are indicated by the very small size of lowermost Paleocene foraminifer faunas, and anomalous nannofossil floras in Hole $465 \mathrm{~A}$. The apparent complete recovery of the Upper
Cretaceous and lower Tertiary interval allows a detailed assessment of any changes in bottom and surface waters.

\section{EXPLANATORY NOTES}

\section{Authorship}

The site-summary chapters are authored by the shipboard scientific party collectively; ultimate responsibility lies with the Co-Chief Scientists. Chapters 2 through 5 present data and discussions for the holes drilled. All site-report chapters follow the general outline given below (primary authorship in parentheses):
A. Site Summary Sheet (Thiede and Vallier)
B. Background and Objectives (Thiede and Vallier)
C. Operations (Thiede and Vallier)
D. Lithologic Summary

1. Sediments (Adelseck, Dean, Koporulin, and Rea) 


\section{Igneous Rocks (Seifert and Windom)}

E. Geochemistry (Dean)

F. Physical Properties (Fujii)

G. Paleomagnetism (Sayre)

H. Correlation of Seismic Reflection Profiles with Drilling Results (Fujii and Vallier)

I. Biostratigraphy

1. Summary (Vincent: Site 463; Boersma: Site 464; Schmidt: Sites 465 and 466).

2. Nannofossils (Schmidt: Cenozoic; Čepek: Cretaceous).

3. Foraminifers (Boersma: Cretaceous and Paleogene; Vincent: Neogene).

4. Radiolarians (Schaaf)

5. Diatoms (Sancetta)

J. Sedimentation Rates (Vincent)

K. Summary and Conclusions (Thiede and Vallier)

The interpretations of individuals have been retained in those parts of the reports for which they were responsible. Where possible, we have included data and interpretations from chapters that deal with special topics, and the authors are cited where appropriate.

Editors within the Technical Reports Unit of the U.S. Geological Survey edit chapters that are wholly or in part written by U.S. Geological Survey employees. They did not have an opportunity to check the nomenclature and style in the introduction and site report chapters. Those chapters, therefore, have not been reviewed for conformity with U.S. Geological Survey editorial standards and stratigraphic nomenclature. Any use of trade names is for descriptive purposes only and does not imply endorsement by the USGS.

\section{Numbering of Sites, Holes, Cores and Samples}

DSDP drill sites are numbered consecutively from the first site drilled by Glomar Challenger in 1968. Site numbers are slightly different from hole numbers. A site number refers to one or more holes drilled while the ship was positioned over one acoustic beacon. These holes could be located within a radius as great as 900 meters from the beacon. Several holes may be drilled at a single site by pulling the drill pipe above the sea floor (out of one hole), moving the ship, and drilling another hole.

The first (or only) hole drilled at a site takes the site number. A letter suffix distinguishes each additional hole at the same site. The first hole takes only the site number; the second takes the site number with suffix "A." It is important, for sampling purposes, to distinguish the holes drilled at a site, because recovered sediments or rocks from different holes usually do not come from equivalent positions in the stratigraphic column.

The cored interval is measured in meters below the sea floor. The depth interval of an individual core is the depth below sea floor that the coring operation began to the depth that the coring operation ended. Each core interval is generally 9.5 meters long, which is the nominal length of a core barrel; however, the coring interval may be shorter or longer (rare). "Cored intervals" are not necessarily adjacent to each other, but may be separated by "drilled intervals." In soft sediments, the drill string can be "washed ahead" with the core barrel in place, but not recovering sediment, by pumping water down the pipe at high pressure to wash the sediment out of the way of the bit and up the space between the drill pipe and wall of the hole.

Cores taken from a hole are numbered serially from the top of the hole downward. Core numbers and their associated cored intervals in meters below the sea floor are normally unique for a hole; however, problems may arise if an interval is cored twice.

Full recovery for a single core is normally 9.28 meters of sediment or rock, which is in a plastic liner $(6.6 \mathrm{~cm}$ inner diameter), plus about a 0.2 -meter-long sample (without a plastic liner) in the core catcher (CC). The core catcher is a device at the bottom of the core barrel which prevents the cored sample from sliding out when the barrel is being retrieved from the hole. The sediment core, which is in the plastic liner, is then cut into 1.5 -meter-long sections and numbered serially from the top of the sediment (Fig. 7). When full recovery is obtained, the sections are numbered from 1 through 7, the last section generally being shorter than 1.5 meters. The core-catcher sample is placed below the last section when the core is described, and labeled "CC"; it is treated as a separate section.

When recovery is less than $100 \%$, and if the sediment or rock is contiguous, the recovered sediment is placed in the top of the cored interval, then 1.5-meter-long sections are numbered serially, starting with Section 1 at the top. (This technique differs from the labeling systems used on Legs 1 through 45 which had a designation called "zero section," but did not have a "number 7 section.") There will be as many sections as needed to accommodate the length of the recovered core (Fig. 7); for example, 3 meters of core sample in plastic liners will be divided into two 1.5-meter-long sections. Sections are cut starting at the top of the recovered sediment, and the last section may be shorter than the normal 1.5-meter length.

When recovery is less than $100 \%$, the sediment's original stratigraphic position in the cored interval is unknown, so we conventionally assign the top of the recovered sediment to the top of the cored interval. This is done for convenience in data handling, and consistency. If recovery is less than $100 \%$ and core fragments are separated, and if shipboard scientists believe that the sediment was not contiguous, then sections are numbered serially and the intervening sections are noted as void, whether it is contiguous or not in the core barrel. The core-catcher sample is described in the coredescription forms beneath the lowest section.

Samples are designated by centimeter distances from the top of each section to the top and bottom of the sample in that section. A full identification number for a sample consists of the following information: leg, site, hole, core number, section number, interval in centimeters from the top of section. For example, a sample identification number " $62-465 \mathrm{~A}-9-3,12-14 \mathrm{~cm}$ " is interpreted as follows: a sample taken at 12 to $14 \mathrm{~cm}$ from the top of Section 3 of Core 9, from the second hole drilled at Site 465 during Leg 62. A similar sample from the core catcher of this core is designated as " 62 465A-9, CC, 12-14 cm." 


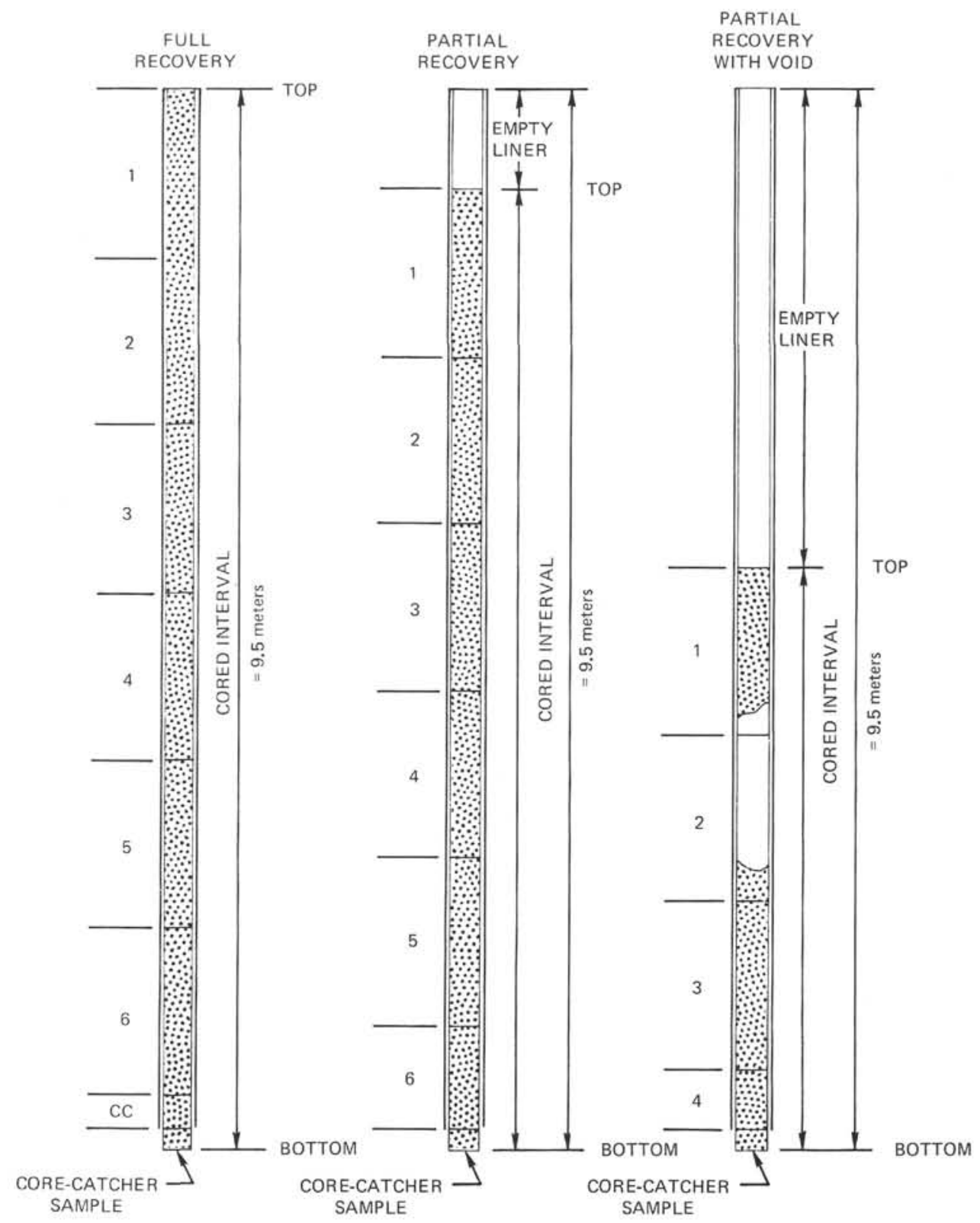

Figure 7. Diagram showing procedure in cutting and labeling of core sections.

The depth below the sea floor for a sample designated " $62-465 \mathrm{~A}-9-3,12-14 \mathrm{~cm}$ " is the sum of the following: the depth to the top of the cored interval for Core 9, which is 115 meters; plus 3 meters for Sections 1 and 2 (each 1.5-m long); plus the $12 \mathrm{~cm}$ depth below the top of Section 3. All these variables add up to 118.12 meters, which theoretically is the sample depth below the sea floor. (Sample requests should refer to a specific interval within a core section, not the level below the sea floor.)

\section{Handling of Cores}

A core normally is cut into 1.5 -meter sections, sealed, and labeled; then the sections are brought into the core laboratory for processing. The following determinations are normally made before the sections are split: gas analysis, thermal-conductivity analysis (soft sedi- ment only), and continuous wet-bulk-density determinations, using the gamma-ray-attenuation porosity evaluation (GRAPE).

The cores are then split longitudinally into "working" and "archive" halves. Samples are extracted from the "working" half, including those for determination of grain-size distribution, mineralogy by X-ray diffraction, sonic velocity by the Hamilton frame method, wetbulk density by a static GRAPE technique, water content by gravimetric analysis, carbon-carbonate content, calcium carbonate content (carbonate bomb), geochemistry, fossil content, etc.

Smear slides from each major lithology and most minor lithologies are prepared and examined with a polarizing petrographic microscope. The archive half is then described and photographed. Physical disturbance by the drill bit, color, texture (for uncemented lithol- 
ogies), sedimentary structure, and composition $( \pm 20 \%)$ of the various lithologies are noted on core-description forms.

After the cores are sampled and described, they are maintained in cold storage aboard Glomar Challenger until they can be transferred to the DSDP repository. Core sections which are removed for organic-geochemistry study are frozen immediately aboard ship and kept frozen. All Leg 62 cores are now stored at the DSDP West Coast Repository (Scripps Institution of Oceanography).

Core descriptions, smear-slide descriptions, carbonate-bomb determinations $\left(\% \mathrm{CaCO}_{3}\right)$, biostratigraphy (data determined primarily aboard ship), carbon-carbonate determinations (at DSDP and at the University of Oslo), and silica and iron content determinations (by the USGS, Denver), serve as the data for the core-form descriptions in this volume. These samples, and their location in the core, are coded with a symbol on the core-description sheets. The key to these codes is shown in Figure 8.

\section{Visual Descriptions}

\section{Sediment Disturbance}

Recovered materials, particularly the soft sediments, may be extremely disturbed. This mechanical disturbance is the result of the coring technique, which uses a large, $25-\mathrm{cm}$-diameter bit with a small, $6.0-\mathrm{cm}$ opening for the core sample. Disturbance categories are indicated on the core-description sheet (in a column) by coded patterns to which the key is in Figure 8. The categories are (1) slightly deformed (bedding contacts slightly bent); (2) moderately deformed (bedding contacts have undergone extreme bowing); (3) very deformed (bedding is extremely disturbed, sometimes showing symmetrical, diapir-like structures and vertical streaks); (4) soupy (water-saturated intervals which have lost all aspects of original bedding).

\section{Sedimentary Structures}

In the soft cores-and even in some harder sedimentary cores-it may be extremely difficult to distinguish natural structures and structures created by the coring process. Thus, the description of sedimentary structures was optional. A column on the core-description form (Fig. 8) may have symbols to indicate typical structures. The key to the set of the structure symbols is in Figure 9.

\section{Color}

Colors of the geologic materials are determined with a Munsell soil-color chart or Geological Society of American rock-color chart. Colors were determined immediately after the cores were split and while they were wet.

\section{Graphic Lithologic Column}

The graphic lithologic column is based on the lithologic classification outlined below. The lithologies and their corresponding symbols are given in Figure 10. Often a single lithology will be represented by a single pattern. Some lithologies are represented by two or more symbols; these symbols may correspond to endmember sediment constituents, such as clay or nannofossil ooze. Normally the symbol for the dominant constituent is placed on the right-hand side of the column, and the symbol for the subordinate constituent will be on the left-hand side of the column (see examples in Fig. 10). The width of each symbol used in combinations is proportional to the abundance of the corresponding end member in the sediment. For example, the left $20 \%$ of the column may have a clay symbol, while the right $80 \%$ of the column may have a nannofossil-ooze symbol. The vertical lines which separate the symbols are shown in Figure 10 with their corresponding percentages and positions in the column.

Because of the difference in the length-to-width ratio between the actual sediment core and the graphic lithologic column, it is not possible to reproduce structures as they appeared in the core (they become highly flattened and distorted). The same is true for concretions and changes of lithology in the cores. As a result, the locations of concretions are shown by a circle with an abbreviation for the type of concretion inside the circle (Fig. 10). If the material is dispersed throughout the sediment, the symbol is used without being encircled. The positions of small "blebs" of ash or other lithologic changes are given by a triangular insert of the appropriate lithologic symbol on the right side of the lithologic column (Fig. 10). This convention applies only to lithologies which do not extend across the entire core. Beds of ash and chert less than $10-\mathrm{cm}$ thick are shown by rows of dots and triangles, respectively, overprinting the symbol for the surrounding lithology (Fig. $10)$; beds greater than $10-\mathrm{cm}$ thick are shown by a different lithologic symbol (Fig. 10).

\section{Text of Core Description}

Format, style, and terminology of the descriptive portion of the core-description sheets (Fig. 8) are not controlled by the "Mandatory Graphic Lithologic Column Scheme,' of JOIDES, beyond the minimal name assignment which is derived from the lithologic classification. Colors and additional information, such as structure and textures, are normally included in the text portion of the core description.

\section{Core Photographs and Physical-Properties Data}

In the site chapters, physical-properties data for each core are presented on the same page as the core photograph (Fig. 11). The data include continuous GRAPE; horizontal, vertical, and undifferentiated sonic velocity; and water content and density by 2-minute GRAPE and by gravimetric chemistry. A key to the symbols for the various measurements is given in Figure 11.

\section{Lithologic Classification}

\section{Introduction}

The sediment classification used for Leg 62 is basically that devised by the JOIDES Panel on Sedimentary Petrology and Physical Properties (SPPP), with modifi- 


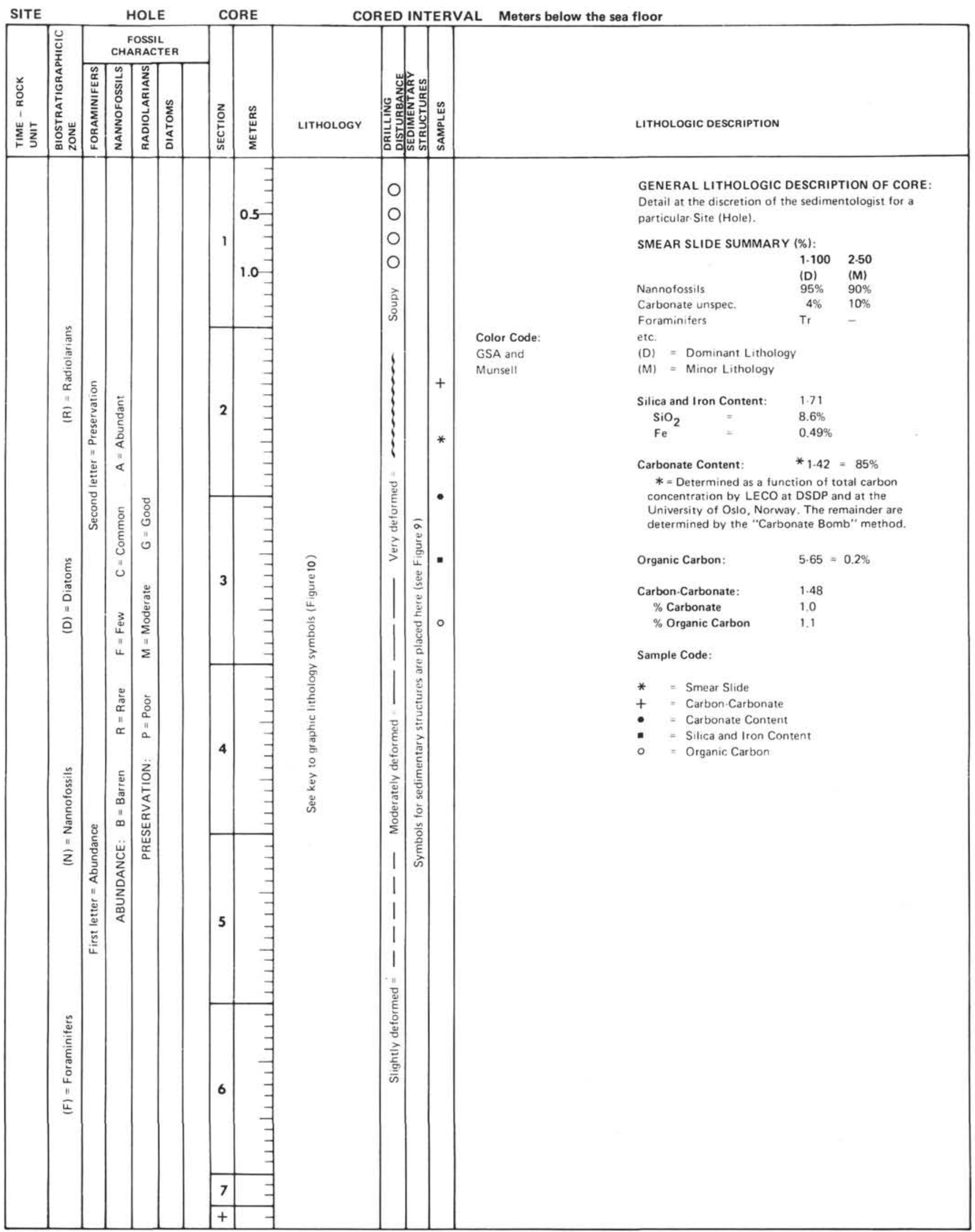

Figure 8. Sample core-description form (sediments), with the sediment-deformation symbols, sample codes, and other general information. 


\begin{tabular}{|c|c|}
\hline \multicolumn{2}{|c|}{$\begin{array}{l}\text { Recommended } \\
\text { Symbol }\end{array}$} \\
\hline $\mathrm{mm}$ & Current ripples \\
\hline$\mu$ & Micro-cross-laminae (including climbing ripples) \\
\hline 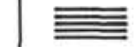 & Parallel bedding \\
\hline ww & Wavy bedding \\
\hline & Flaser bedding \\
\hline 00 & Lenticular bedding \\
\hline & Cross-stratification \\
\hline$\Omega$ & Slump blocks or slump folds \\
\hline & Load casts \\
\hline$\varnothing$ & Scour \\
\hline$\cdots$ & Normal graded bedding \\
\hline$\because$ & Reverse graded bedding \\
\hline 20200 & Convolute and contorted bedding \\
\hline II & Water-escape pipes \\
\hline$\checkmark$ & Mudcracks \\
\hline & Sharp contact \\
\hline$\mu$ & Scoured, sharp contact \\
\hline-- & Gradational contact \\
\hline 00 & Imbrication \\
\hline & Fining-upward sequence \\
\hline & Coarsening-upward sequence \\
\hline 1 & Interval over which a specific structure occurs in core \\
\hline$s$ & Bioturbation-minor $(0-30 \%$ of surface area) \\
\hline 18 & Bioturbation-moderate $(30-60 \%$ of surface area) \\
\hline m & Bioturbation-strong (more than $60 \%$ of surface area) \\
\hline
\end{tabular}

Figure 9. Symbols for sedimentary structures.

cations as outlined below. As a first approximation, we considered each sediment to be a mixture of biogenic and nonbiogenic components. Except in clays, authigenic components (mainly $\mathrm{Fe}-\mathrm{Mn}$ micronodules and zeolites) usually constitute less than $10 \%$ of the sedi- ment. Any component which constitutes more than $10 \%$ of the sediment may be used as a qualifier in the sediment name. No more than two qualifiers are used in a name, the last qualifier being the more-abundant component.

We have divided the frequencies of sediment components into four major groups: $<10 \%, 10$ to $30 \%, 30$ to $60 \%$, and $>60 \%$. These boundaries have been used for both calcareous and siliceous components, and thus depart slightly from the SPPP classification, which employs only one major subdivision $(50 \%)$ in the biogenic siliceous sediments: $<50 \%$ siliceous fossils $=$ siliceous clay, $>50 \%$ siliceous fossils $=$ siliceous ooze . To be consistent, we subdivided both siliceous and calcareous pelagic sediment facies in the same way.

\section{Descriptive Data}

Sediment and rock names are defined solely on the basis of composition and texture. Composition is most important for description of biogenic deposits characteristic of open marine conditions, texture becoming more important for the classification of non-biogenic and hemipelagic deposits. These data are primarily determined aboard the ship by visual estimates "in smear slides" with the aid of a microscope.

\section{Basic Sediment Types}

\section{Nonbiogenic Sediments}

Nonbiogenic sedimentary components are treated entirely on the basis of texture (sand, silt, or clay), according to Shepard's (1954) classification (Fig. 12). Because no separate category is used for "pelagic clay," it is simply referred to as "clay." The texture is determined entirely on the estimated percentages of sizes of nonbiogenic material from smear-slide descriptions. The term "clay" under composition in the smear-slide description is taken to represent all clay-sized material, regardless of mineralogy. Silt- and sand-sized materials appear in the smear-slide descriptions as percentages of component minerals (e.g., quartz, feldspar, heavy minerals, pyrite, etc.), where they can be determined.

\section{Biogenic Siliceous Sediments}

Biogenic siliceous sediments are those that contain more than $30 \%$ siliceous microfossils. Sediments containing between $10 \%$ and $30 \%$ siliceous microfossils should contain the name(s) of the microfossil(s) as qualifiers. The following terminology is used for siliceous biogenic sediments:

1) Soft: siliceous ooze (radiolarian ooze, diatom ooze, etc., depending on the dominant fossil component);

2) Hard: radiolarite, diatomite, chert, or porcellanite. The term "chert" in the past has been used in a very broad sense to designate almost any form of recrystallized silica. The term porcellanite (which also had a very broad usage in the past) will be used here to refer to "low density, more or less porous and dull-lustered varieties of 'chert' made of opaline silica or cristobalite...." (Lancelot, 1973). "Chert," as used here, will 


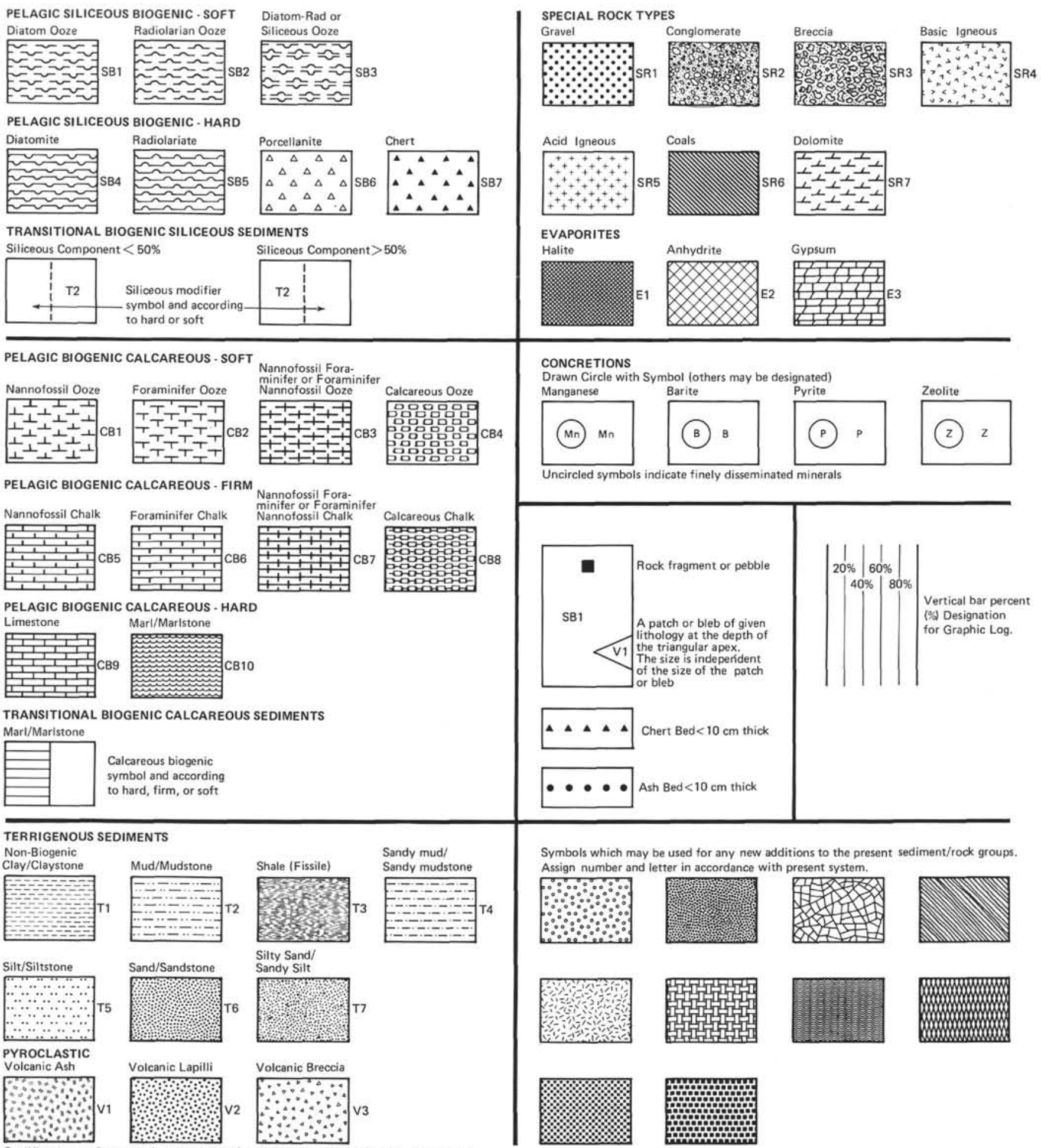

Qualifiers Letter Overprint (as per examples) Zeolite AI Glauconite A3 Siderite A4 (other may be designated)

Figure 10. Lithologic symbols.

have a narrower scope than that of past usage, and will refer to "hard nodules and sometimes beds, that are largely quartz and (or) chalcedony, and show a conchoidal fracture and a vitreous luster...." (Lancelot, 1973).
3) Compositional qualifiers: diatoms and radiolarians may be the principle components; thus, one or two qualifiers may be used, for example:

Indeterminate siliceous fossils: siliceous ooze, chert, or porcellanite. 


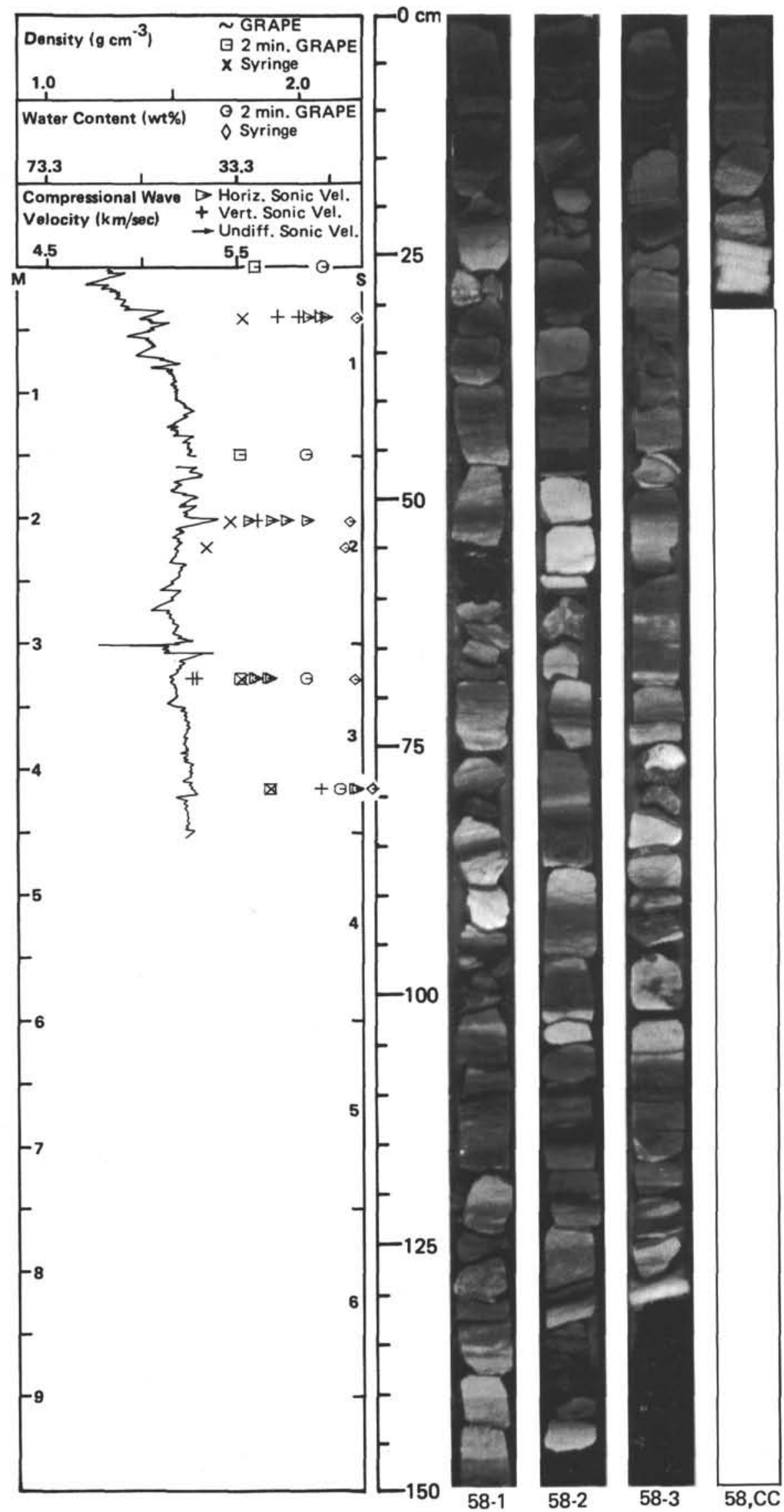

Figure 11. Sample core photograph showing physical properties display of $463-58$, simulated GRAPE. 


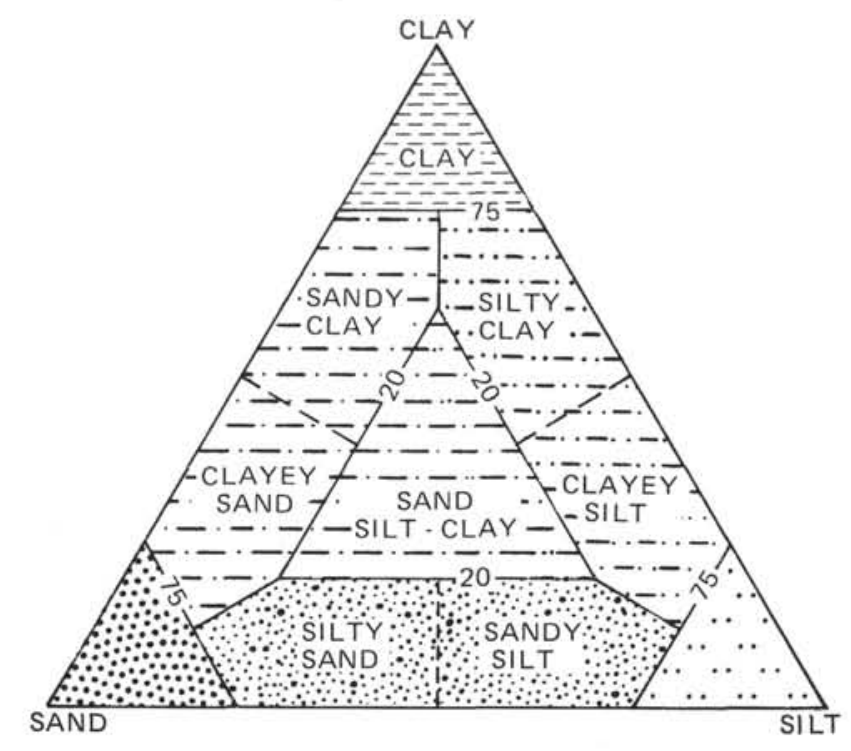

Figure 12. Textural classification of clastic sediments (after Shepard, 1954).

Radiolarians only: radiolarian ooze, or radiolarite Diatoms only: diatom ooze, or diatomite

Diatom < radiolarians: diatom radiolarian ooze, or diatom radiolarite

Diatom > radiolarians: radiolarian diatom ooze, or radiolarian diatomite

The order of the two modifiers in the terms is dependent on the dominant fossil type. The dominant component is listed last and the minor component is listed first. The terminology for mixtures of clay with diatom sediments is:

\begin{tabular}{|c|c|c|}
\hline $\begin{array}{c}\text { Biogenic Siliceous } \\
\text { Fossil Particles } \\
(\%)\end{array}$ & $\begin{array}{c}\text { Nonbiogenic } \\
\text { Particles } \\
(\%)\end{array}$ & Lithologic Type \\
\hline$<10$ & 90 & $\begin{array}{l}\text { Clay (soft) } \\
\text { Claytone (hard) }\end{array}$ \\
\hline $30-10$ & $70-90$ & $\begin{array}{l}\text { Diatom clay (soft) } \\
\text { Diatom claystone (hard) }\end{array}$ \\
\hline $60-30$ & $40-70$ & $\begin{array}{l}\text { Clayey diatom ooze (soft) } \\
\text { Clayey diatomite (hard) }\end{array}$ \\
\hline $100-60$ & $0-40$ & $\begin{array}{l}\text { Diatom ooze (soft) } \\
\text { Diatomite (hard) }\end{array}$ \\
\hline
\end{tabular}

If radiolarians are the dominant siliceous microfossil, the terms "radiolarian" and "radiolarite" are substituted for "diatom" and "diatomite," respectively. The term "siliceous" may be used if the fossil type is indeterminate. Likewise, other textural terms for the nonbiogenic components can be substituted for clay in accordance with Shepard's (1954) classification (e.g., silty diatom ooze, diatom silty clay, etc.).

\section{Biogenic Calcareous Sediment}

Calcareous biogenic sediments are distinguished by a $\mathrm{CaCO}_{3}$ content in excess of $30 \%$. There are two classes: (1) biogenic calcareous sediments, that contain 60 to $100 \%$ biogenic $\mathrm{CaCO}_{3}$, and (2) transitional biogenic calcareous sediments, that contain 30 to $60 \%$ biogenic $\mathrm{CaCO}_{3}$.
1) For biogenic calcareous sediment, with 60 to $100 \%$ biogenic $\mathrm{CaCO}_{3}$, the following terminology is used:

Soft: calcareous ooze

Firm: chalk

Hard and cemented: limestone

If nannofossils and foraminifers are the principal components, then one or two qualifiers may be used, as in the following examples:

Indeterminate carbonate fossils: calcareous ooze, calcareous chalk, or calcareous limestone

Foraminifers $0-10 \%$, nannofossils $90-100 \%$ : nannofossil ooze, nannofossil chalk, or nannofossil limestone

Foraminifers $10-30 \%$, nannofossils $60-90 \%$ : foraminifer-nannofossil ooze, foraminifer-nannofossil chalk, or foraminifer-nannofossil limestone

Foraminifers $30-60 \%$, nannofossils $40-70 \%$ : nannofossil-foraminifer ooze, nannofossil-foraminifer chalk, or nannofossil-foraminifer limestone

2) For transitional biogenic calcareous sediments, with 30 to $60 \%$ biogenic $\mathrm{CaCO}_{3}$, the following terminology is used:

Marl or marlstone: $30-60 \% \mathrm{CaCO}_{3}$, nonbiogenic components greater than siliceous biogenic components:

Soft: calcareous marl, foraminifer marl, or nannofossil marl.

Hard: calcareous marlstone, foraminifer marlstone, or nannofossil marlstone.

Note that the use of the terms "marl" or "marlstone" differ from the SPPP classification. The panel's classification used "marly" as an adjective modifying ooze, chalk, or limestone (e.g., "'marly limestone"), to denote sediments which had 30 to $60 \%$ biogenic carbonate. Our terminology for mixtures of clay with nannofossil sediments is as follows:

\begin{tabular}{|c|c|c|}
\hline $\begin{array}{c}\text { Biogenic } \\
\text { Calcareous } \\
\text { Fossil } \\
\text { Particles } \\
(\%)\end{array}$ & $\begin{array}{c}\text { Nonbiogenic } \\
\text { Particles } \\
(\%)\end{array}$ & Lithologic Type \\
\hline $0-10$ & $90-100$ & $\begin{array}{l}\text { Clay (soft) } \\
\text { Claystone (hard) }\end{array}$ \\
\hline $30-10$ & $70-90$ & $\begin{array}{l}\text { Nannofossil clay (soft) } \\
\text { Nannofossil claystone (hard) }\end{array}$ \\
\hline $60-30$ & $40-70$ & $\begin{array}{l}\text { Nannofossil marl (soft) } \\
\text { Nannofossil marlstone (hard) }\end{array}$ \\
\hline $100-60$ & $0-40$ & $\begin{array}{l}\text { Nannofossil ooze (soft) } \\
\text { Nannofossil chalk (firm) } \\
\text { Nannofossil limestone (hard) }\end{array}$ \\
\hline
\end{tabular}

Other terms may be substituted for nannofossil, such as (1) "foraminifer, nannofossil-foraminifer," if foraminifers are present in the percentages as discussed, or (2) "calcareous," if the fossil type is indeterminate. Likewise, other textural terms for the nonbiogenic components can be substituted for clay in accordance with Shepard's (1954) classification (e.g., silty nannofossil ooze, foraminifer silty clay, etc.).

Biogenic ooze: $30-60 \% \mathrm{CaCO}_{3}$, siliceous biogenic components greater than nonbiogenic components. 
Calcareous components greater that siliceous components (examples): radiolarian nannofossil ooze (chalk), diatom foraminifer ooze, siliceous limestone.

Siliceous components greater than calcareous components (examples): nannofossil diatom ooze (diatomite), foraminifer radiolarian ooze (radiolarite).

In some of the sediments encountered on Leg 62 , the original calcareous lithology has been replaced by silica (generally $>40 \% \mathrm{SiO}_{2}$ ). In these cases, we modify the original name with the word "silicified" (e.g., silicified chalk, or silicified limestone).

\section{Volcanogenic Sediments}

Pyroclastic rocks are described according to the textural and compositional scheme of Wentworth and Williams (1932). The textural groups are: $>32 \mathrm{~mm}$, volcanic breccia; 4 to $32 \mathrm{~mm}$, volcanic lapilli; $<4$, volcanic ash (tuff, if indurated). These pyroclastic rocks are described as vitric, crystal, or lithic.

\section{Carbon-Carbonate Analysis}

Because of funding problems, DSDP was unable to provide basic laboratory support and carbon-carbonate analyses. Therefore, we had to use two different laboratories to satisfy our requirements. Sediment samples were analyzed for carbon and carbonate content at the DSDP sediment laboratory, on a Leco WR-12 Carbon Analyzer by U.S. Geological Survey personnel under the supervision of T. Vallier, and by the chemical laboratory of the Department of Geology, University of Oslo, under the supervision of J. Thiede. Sample preparation procedures are outlined in Boyce and Bode (1972) and Bode (1973). Discussions of the Leco WR-12 analyzer are in Bode (1973). Accuracy and precision of the results are as follows: total carbon, $\pm 0.3 \%$ (absolute); organic carbon, $\pm 0.06 \%$ (absolute); $\mathrm{CaCO}_{3}$, $\pm 3 \%$ (absolute).

The sample interval is designated by two numbers: the section number, followed by the top of the sample interval; for example: a sample from Section 2 at $11 \mathrm{~cm}$ with $7.1 \%$ carbonate and $0.7 \%$ organic carbon will be presented on the core forms as follows:

$$
\begin{gathered}
\text { Carbon-Carbonate 2-11 } \\
\% \text { Carbonate } 7.1 \\
\% \text { Organic Carbon } 0.7
\end{gathered}
$$

Most carbonate is bonded with calcium to form calcium carbonate. Other cations may be present, but generally make up only a small part. Therefore, "percent carbonate" is taken to be the same as percent calcium carbonate.

\section{Carbonate Content}

Percent $\mathrm{CaCO}_{3}$ was also determined aboard ship by the "carbonate bomb" technique (Müller and Gastner, 1971), at the University of Oslo under the supervision of J. Thiede by Leco total-carbon determinations, and at Scripps under the supervision of E. Vincent by a technique modified from the carbonate bomb. In the car- bonate-bomb procedure, a sample is powdered and treated with $\mathrm{HCl}$ in a closed cylinder. Any resulting $\mathrm{CO}_{2}$ pressure is proportional to the $\mathrm{CaCO}_{3}$ content of the sample. Application of the calibration factor to the manometer reading $(\times 100)$ yields percent $\mathrm{CaCO}_{3}$. $\mathrm{Er}$ ror can be as low as $1 \%$ for sediments high in $\mathrm{CaCO}_{3}$, and in general an accuracy within 2 to $5 \%$ can be obtained.

Samples run at the University of Oslo by Leco totalcarbon determinations are distinguished from those run by the carbonate bomb method by use of an asterisk preceding the section and sample interval. These samples were run following standard Leco procedures referred to in the section on carbon-carbonate analysis. The carbonate content is determined by multiplying the total carbon content by 8.33 . This carbonate determination assumes no contribution of carbon by organic compounds. Care was taken to use this method only in parts of the section where organic carbon (as determined by carbon-carbonate analysis) was very low. An accuracy in calcium carbonate of $-2 \%$ to $+5 \%$ is obtained.

These data are present on the core forms (Fig. 8). The sample interval is designated by two numbers: the section number, followed by the top of the sample interval; for example, a sample from Section 2 from $11 \mathrm{~cm}$ with $90 \%$ calcium carbonate is presented on the core form as follows:

$$
\begin{aligned}
& \text { Carbonate Content } \\
& * 2-11=90 \%
\end{aligned}
$$

\section{Silica and Iron Content}

Silica $\left(\% \mathrm{SiO}_{2}\right)$ and iron $(\% \mathrm{Fe})$ determinations were run on the same samples and were provided by W. E. Dean of the USGS in Denver. Silica determinations were run using standard $\mathrm{x}$-ray-fluorescence techniques, and iron was determined by emission spectrophotometry. Values for weight percent iron are not accurate below $0.05 \%$. Silica values are precise to $\pm 5 \%$ of the value, and iron values are precise to $\pm 15 \%$ of the value above $0.05 \%$.

Values of silica and iron content are presented on the core forms (Fig. 8). The sample interval is designated in the same manner as that for other data and is presented on the core form as follows:

$$
\begin{gathered}
\text { Silica and Iron Content } 1-26 \\
\mathrm{SiO}_{2}=6.0 \% \\
\mathrm{Fe}=0.57 \%
\end{gathered}
$$

\section{Organic Carbon}

Besides the Leco determination, measurements of organic-carbon concentrations were also carried out for several samples at each of Sites 463,465 , and 466 , using the CHN analyzer aboard Glomar Challenger. These are considered rough values, and no strict value of accuracy has been calculated.

Values for organic-carbon content were presented on the core forms (Fig. 8) as follows: Organic Carbon: $5-65=0.2 \%$. 


\section{Biostratigraphy}

The time scales compiled by the shipboard paleontologists are shown in Figures 13, 14, and 15. The calibration of the zone boundaries to a radiometric scale follows that of Berggren (1973) and Van Couvering and Berggren (1977) for the Neogene, and Hardenbol and Berggren (1978) for the Paleogene. For the Cretaceous, the zone schemes and stratigraphic ranges presented by Thierstein (1976) form the basis for age determinations. These, in turn, are correlated to the numeric time scale proposed by van Hinte (1976). Late Cretaceous and Paleogene planktonic zones were derived from the zonations of Postuma (1971), van Hinte (1976), Premoli Silva and Bolli (1973), Gartner (1971), and Premoli Silva and Boersma (1977). Individual zones were then related to the time scale and zonation of van Hinte (1976) for standardization. The correlation of Blow's (1969) planktonic-foraminifer zones with those of Martini (1971) for calcareous nannoplankton, and the assignment of absolute ages to the zone boundaries, are from Berggren (1973), Berggren and Van Couvering (1974), and Van Couvering and Berggren (1977). The ages recognized for the radiolarian and diatom zone boundaries are those proposed by Theyer and Hammond (1974a, b) and Burckle (1972), respectively. The paleomagnetic time scale is from Van Couvering and Berggren (1977) and Theyer and Hammond (1974a, b).

\section{Igneous Rocks}

All igneous rocks were split with a rock saw into working and archive halves and were described and sampled aboard ship. Figure 16 shows a composite visual core-description form used for the description of igneous rocks recovered on Leg 62 . On this form, each section of a core is described under a set of five column headings: (1) piece number, (2) graphic representation, (3) orientation, (4) shipboard studies, and (5) alteration.

In the graphic-representation column, each piece is accurately drawn, and features such as texture, glassy margins, or vesicles are coded according to the symbols given in Figure 17. Two closely spaced horizontal lines in this column indicate the location of styrofoam spacers taped between pieces inside the liner. Each piece is numbered sequentially from the top of the section, beginning with the number 1 (piece-number column). Pieces are labeled on the rounded surface, rather than the flat, slabbed face. Pieces which fit together before splitting were given the same number, but are consecutively lettered: 1A, 1B, 1C, etc. Spacers were placed only between pieces which did not fit together; those pieces were given different numbers. Spacers may or may not indicate missing material (not recovered) between pieces. All cylindrical pieces longer than the diameter of the liner have arrows in the orientation column, indicating that top and bottom have not been reversed as a result of drilling and recovery. Arrows also appear on the labels of these pieces on both archive and working halves.

The column marked "Shipboard Studies" designates the location and the type of measurements made on a sample aboard ship. The column headed "Alteration" gives the degree of alteration, using the code given in Figure 17. Below each set of five descriptive columns is the designation for core and section for which these data apply.

Figure 16 gives the outline for core descriptions of igneous rocks in the right-hand margin of the visual coredescription form. If more than one core appears on the same core form, these data are listed below the description of the first core, using the same format. As many cores as space allows are included on one visual coredescription form. When space for descriptions is inadequate on this form, these data appear on the following or facing page. However, in no case does information from one core appear on successive core forms.

For each core, the core number, sections, and depth interval of recovered rocks are listed, followed by the major and minor rock types and a short description. Thin-section data are given below this, then shipboard data.

We informally classified igneous rocks recovered on Leg 62 according to mineralogy and texture determined from visual inspection of hand specimens and thin sections. Standard rock names, such as basalt, trachyte and dolerite, are based on mineralogical compositions.

\section{REFERENCES}

Berggren, W. A., 1973. The Pliocene time scale: calibration of planktonic foraminiferal and calcareous nannoplankton zones. Nature, 243:391-397.

Berggren, W. A., and Van Couvering, J. A., 1974. The late Neogene: biostratigraphy, biochronology and paleoclimatology of the last 15 million years in marine and continental sediments. Palaeogeog., Palaeoecol., Palaeoclimatol., 16:1-216.

Blow, W. H., 1969. Late middle Eocene to Recent planktonic foraminiferal biostratigraphy. In Brönnimann, P., and Renz, H. H. (Eds.), Proceedings of the First International Conference on Planktonic Microfossils, Geneva, 1967: Leiden (Brill), pp. 199421.

Bode, G. W., 1973. Carbon and Carbonate Analyses-Leg 18. In Kulm, L. D., von Huene, R., et al., Init. Repts. DSDP, 18: Washington (U.S. Govt. Printing Office), 1069-1076.

Boyce, R. E., and Bode, G. W., 1972. Carbon and carbonate analyses, Leg 9. In Hays, J. D., et al., Init. Repts. DSDP, 9: Washington (U.S. Govt. Printing Office), 797-816.

Bradshaw, J. S., 1959. Ecology of living foraminifera in the North and equatorial Pacific Ocean. Cushman Found. Foram. Res., $10: 25-64$.

Burckle, L. H., 1972. Late Cenozoic planktonic diatom zones from the eastern equatorial Pacific. Beih. Nova Hedwigia-Heft, 39:217246.

Chase, T. E., Menard, H. W., and Mammerickx, J., 1971. Topography of the North Pacific: La Jolla (Univ. Calif.).

Fisher, A. G., Heezen, B. C., Boyce, R. E., et al., 1970. Geological history of the western North Pacific. Science, 168:1210-1214.

Gartner, S., 1971. Calcareous nannofossils from the JOIDES Blake Plateau core and revision of Paleogene nannofossil zonation. Tulane Stud. Geol. Paleont., 8:101-121.

Hardenbol, J., and Berggren, W. A., 1978. A new Paleogene numerical time scale. Am. Assoc. Petrol. Geol. Stud. Geol., 6:213-234.

Lancelot, Y., 1973. Chert and silica diagenesis in sediments from the central Pacific. In Winterer, E. L., Ewing, J. I., et al., Init. Repts. $D S D P, 17$ : Washington (U.S. Govt. Printing Office), 377-405.

McGowan, J. A., 1974. The Biology of the Oceanic Pacific: Corvallis (Oregon St. Univ.).

Martini, E., 1971. Standard Tertiary and Quaternary calcareous nannoplankton zonation. In Farinacci, A. (Ed.), Proceedings of the Second Planktonic Conference, Roma 1970 (Vol. 2):739-785. 
Müller, G., and Gastner, M., 1971. The "Karbonat-Bombe," a simple device for determining carbonate content in sediments, soils and other materials. N. Jahrb. Mineral. Monatsh., 10:466-469.

Pitman, W. C., Larson, R. L., and Herron, E. M., 1974. Magnetic Lineation of the Oceans: Boulder (Geol. Soc. Am).

Postuma, J. A., 1971. Manual of Planktonic Foraminifera: Amsterdam (Elsevier).

Premoli-Silva, I., and Boersma, A., 1977. Cretaceous planktonic foraminifera, DSDP Leg 39 (South Atlantic). In Supko, P. R., Perch-Nielsen, K., et al., Init. Repts. DSDP, 39: Washington (U.S. Govt. Printing Office), 615-642.

Premoli-Silva, I., and Bolli, H. M., 1973. Late Cretaceous to Eocene planktonic foraminifera and stratigraphy of Leg 15 sites in the Caribbean. In Edgar, N. T., Saunders, J. B., et al., Init. Repts. DSDP, 15: Washington (U.S. Govt. Printing Office), 499-548.

Riedel, W., and Sanfilippo, A., 1971. Cenozoic radiolaria from the western tropical Pacific, Leg 7. In Winterer, E. L., Riedel, W. R., et. al., Init. Repts. DSDP, 7, Pt. 2: Washington (U.S. Govt. Printing Office), 695-795.

, 1974. Radiolaria from the west-central Indian Ocean and Gulf of Aden, DSDP Leg 24. In Fisher, R. L., Bunce, E. T., et al., Init. Repts. DSDP, 24: Washington (U.S. Govt. Printing Office), 997-1026.

Shepard, F. P., 1954. Nomenclature based on sand-silt-clay ratios. $J$. Sediment. Petrol., 24:151-158.
Sverdrup, H. N., Johnson, M. W., and Fleming, P. H., 1942. The Oceans, Their Physics, Chemistry and General Biology: Englewood Cliffs (Prentice Hall).

Tappan, H., and Loeblich, A. R., 1971. Geobiologic implications of fossil phytoplankton evolution and time-space distribution. In Kosanke, R., and Cross, A. T. (Eds.), Geol. Soc. Am. Spec. Paper, 127:247-340.

Theyer, F. and Hammond, S. R., 1974a. Paleomagnetic polarity sequence and radiolarian zones, Brunhes to Polarity Epoch 20. Earth Planet. Sci. Lett., 22:307-319.

1974b. Cenozoic magnetic time scale in deep sea cores: completion of the Neogene. Geology, 2:487-492.

Thierstein, H. R., 1976. Mesozoic calcareous nannoplankton biostratigraphy of marine sediments. Mar. Micropaleont., 1:325-362.

Van Couvering, J. A., and Berggren, W. A., 1977. The biostratigraphical basis of the Neogene time-scale. In Kauffman, E., and Hazel, J. E. (Eds.), New Concepts and Methods of Biostratigraphy: Stroudsburg (Dawden, Hutchinson, Ross), pp. 283-306.

van Hinte, J. E., 1976. A Cretaceous time scale. Bull. Am. Assoc. Petrol. Stud. Geol., 6::498-516.

Vincent, E., 1975. Neogene planktonic foraminfera from the central North Pacific, Leg 32, Deep Sea Drilling Project. In Larson, R. L., Moberly, R., et al., Init. Repts. DSDP, 32: Washington (U.S. Govt. Printing Office), 765-801.

Wentworth, C. K., and Williams, H., 1932. The classification and terminology of the pyroclastic rocks: report of the Commission on Sedimentation. Bull. Nat. Res. Conv., 80:10-53. 


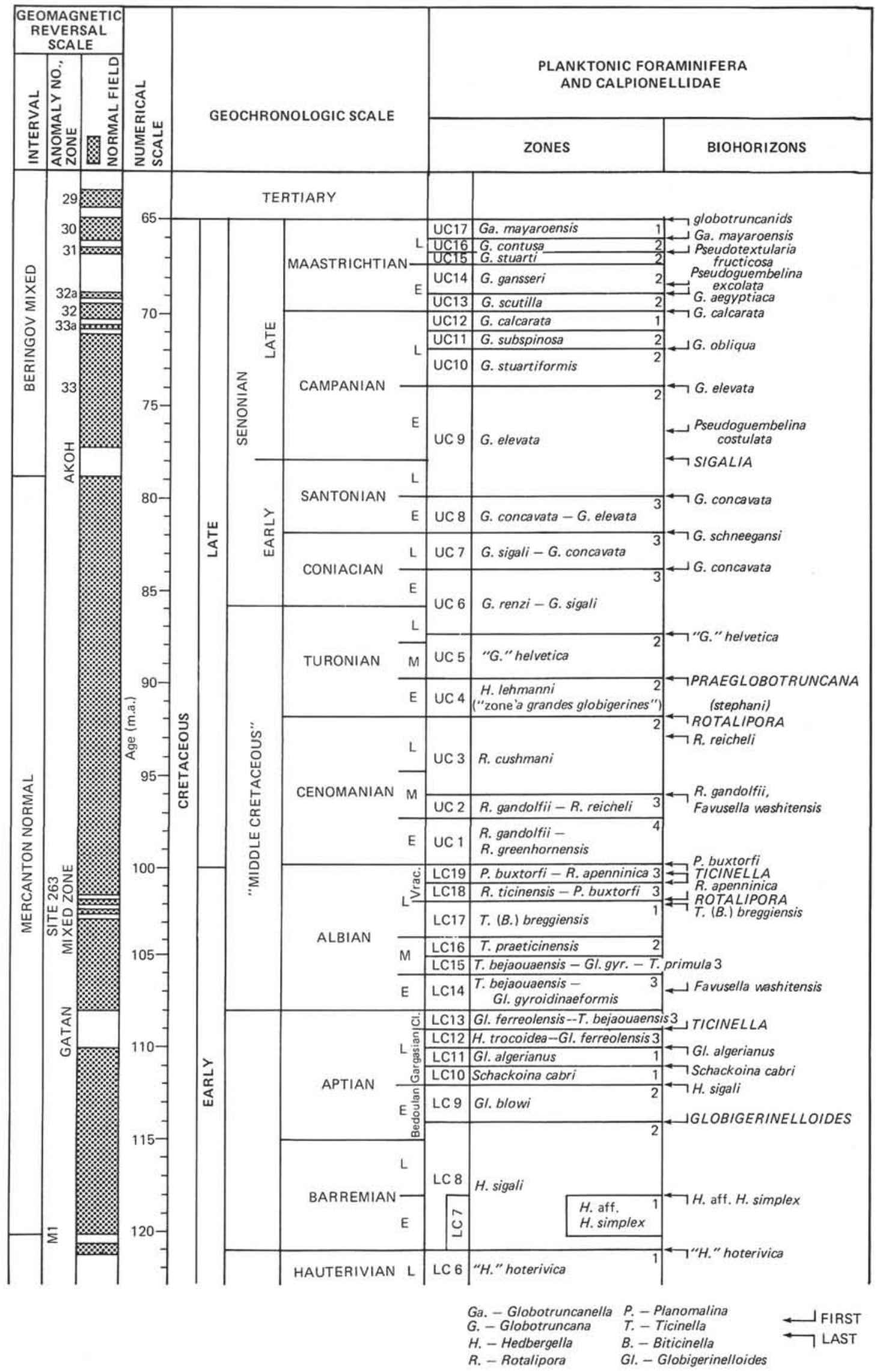

Figure 13. Cretaceous time scale from van Hinte (1976). 
INTRODUCTION, PRINCIPAL RESULTS, AND EXPLANATORY NOTES

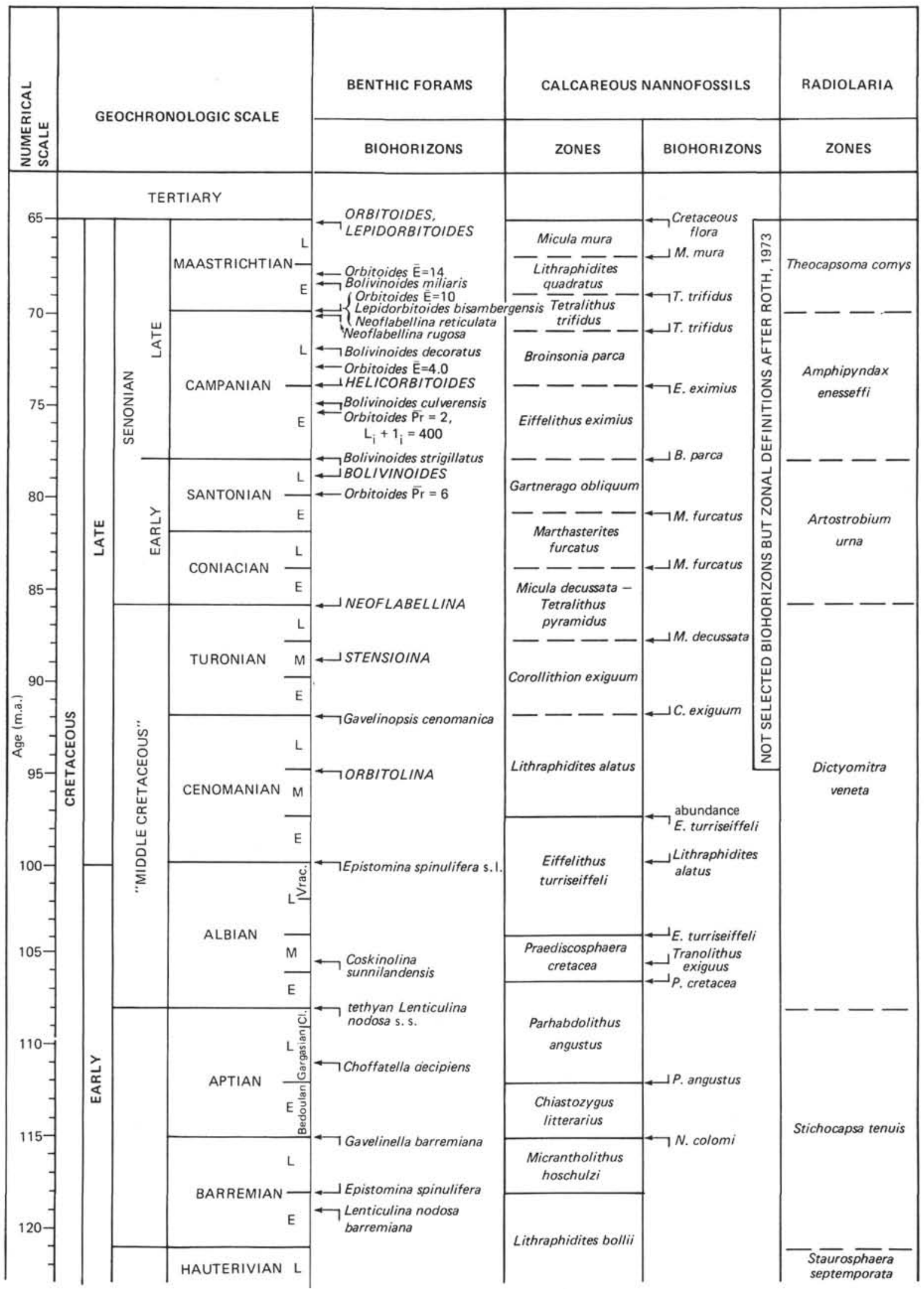

Figure 13. (Continued). 


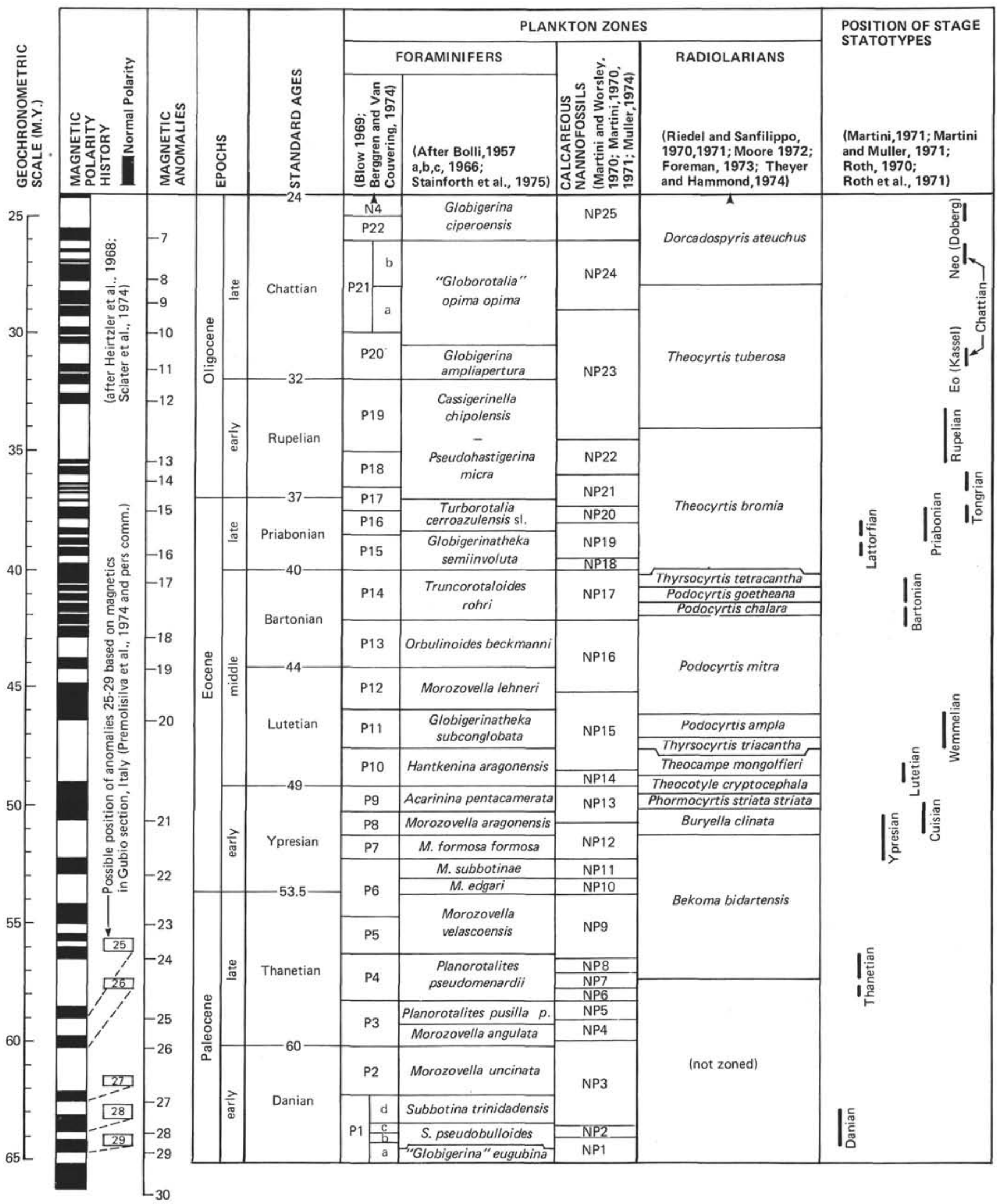

Figure 14. Paleogene zonations and time scale (Hardenbol and Berggren, 1978). 
INTRODUCTION, PRINCIPAL RESULTS, AND EXPLANATORY NOTES

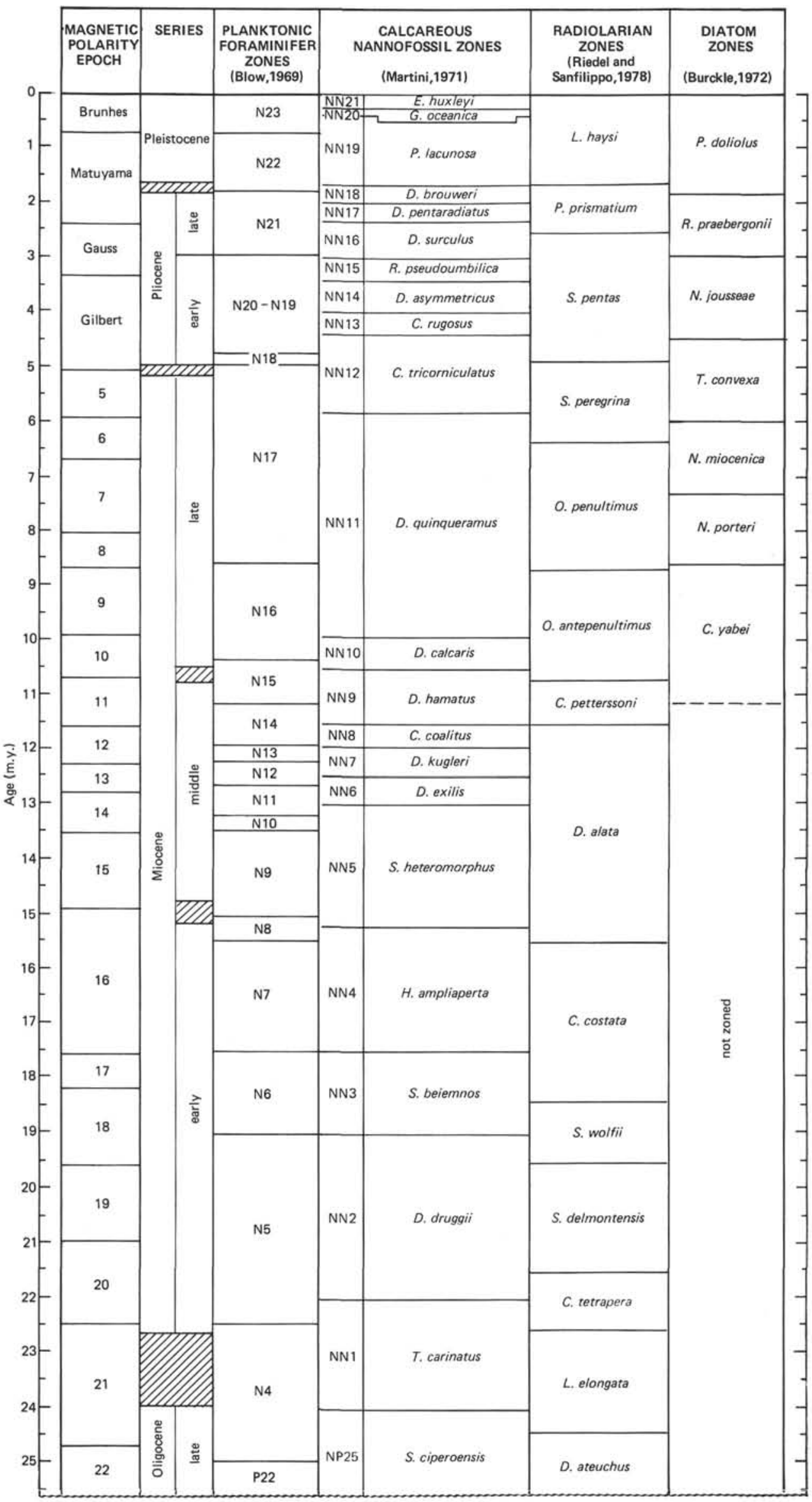

Figure 15. Neogene zonations and time scale. 


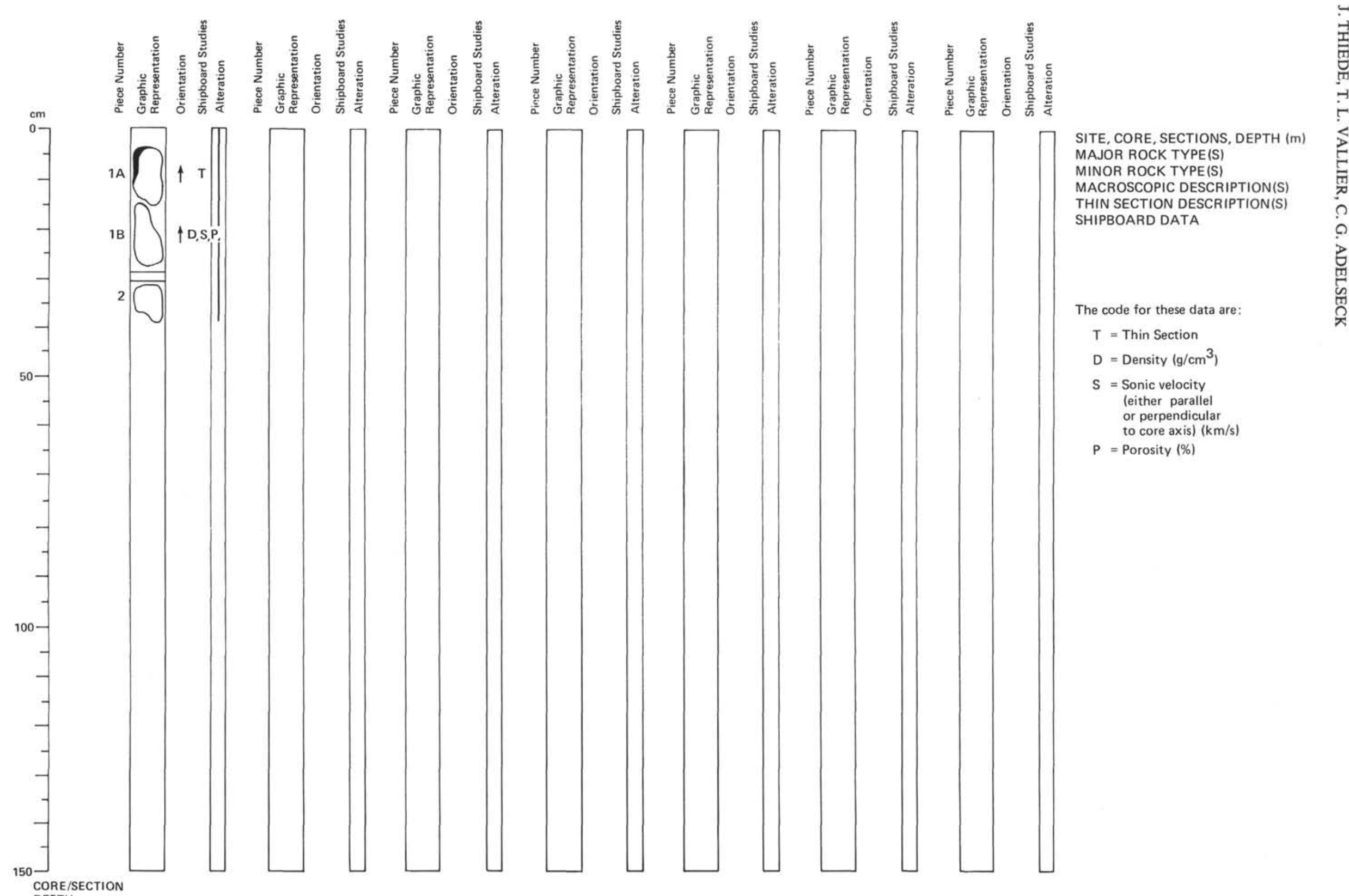

Figure 16. Visual core description form for igneous rocks. 
INTRODUCTION, PRINCIPAL RESULTS, AND EXPLANATORY NOTES

TEXTURE AND STRUCTURE

Used in graphic

representation column

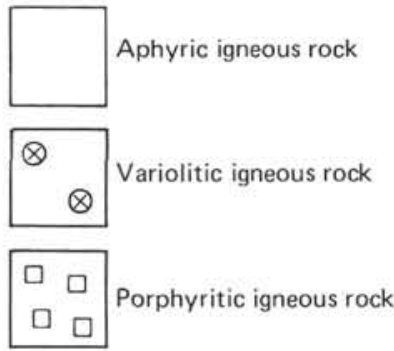

$$
\begin{array}{|cc|l|}
\hline 0 & 0 & \\
0 & 0 & \\
0 & 0 & 0 \\
0 & 0 & \text { Vesicles } \\
0 & 0 & 0 \\
\hline
\end{array}
$$

स्स:영

D. Breccia

. 0.0 (as graphic

0.0 as possible)

(1)
WEATHERING: ALTERATION

Used in alteration column

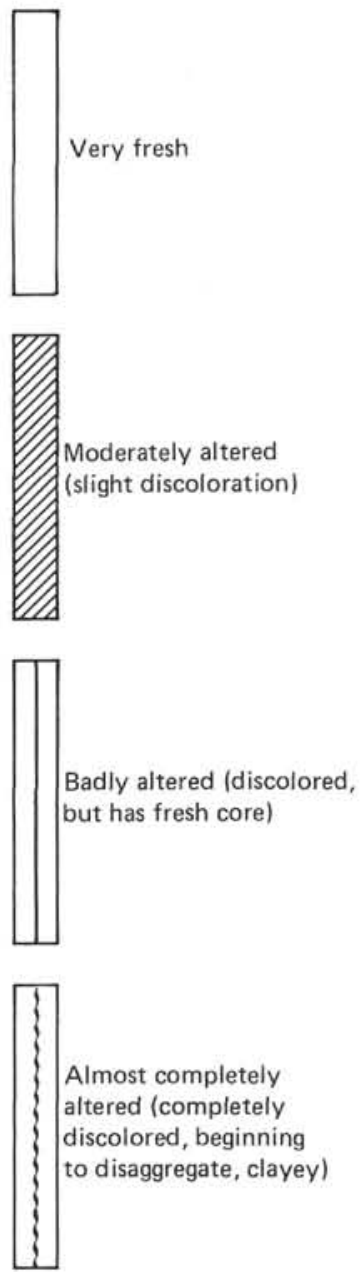

Figure 17. Symbols used on Leg 62 for igneous rocks. 